\title{
LINGUISTIC LANDSCAPE AND WHAT IT TELLS US ABOUT THE INTEGRATION OF THE RUSSIAN LANGUAGE INTO ISRAELI ECONOMY (1)
}

\author{
Maria Yelenevskaya ${ }^{1} \&$ Larisa Fialkova ${ }^{2}$ \\ ${ }^{1}$ Technion-Israel Institute of Technology \\ Technion City, 3200003 Haifa, Israel \\ ${ }^{2}$ The University of Haifa \\ Ave. Abakhoushy Mount Carmel, 3498838 Haifa, Israel
}

\begin{abstract}
This essay analyzes the use of Russian in the linguistic landscape of Israel. Despite continuing hegemony of Hebrew, Russian has penetrated all spheres of public life, although concessions to multilingualism in Israeli society are hesitant and unsystematic. Russian written texts marking urban areas are unevenly distributed and reveal ethnic and social stratification of Israeli cities. The concentration of Russian signs is highest in business and commercial areas, where they target both domestic and international customers. The article focuses on the use of Russian in language-intensive domains and traces its influence on the symbolic economy in which cultural symbols are used as a marketing strategy.
\end{abstract} economy

Keywords: linguistic landscape, multilingualism, immigrants, linguistic resources, symbolic

\section{INTRODUCTION}

Linguistic landscape (LL) is a burgeoning subfield of sociolinguistics investigating what written language in the public sphere reveals about ethnolinguistic vitality of majority and minority groups, power distribution between speakers of different languages and symbolic struggle for visibility in public places (Gorter 2006: 1-2). The definition serving as the basis for many LL projects was formulated by Landry and Bourhis:

The language of public road signs, advertising billboards, street names, place names, commercial shop signs, and public signs on government buildings combines to form the linguistic landscape of a given territory, region, or urban agglomeration (1997: 25).

LL is presented in this definition as static, while in a contemporary city it also includes moving objects: running lines on video screens; advertising on vehicles, car stickers, text on T-shirts and accessories (Marten et al. 2012). There are also texts on banners carried by political protestors, and "walking" advertisers with slogans on their chests and backs. Dynamism of the LL is manifested in its changes over time (Pavlenko 2010). A case in point is mass renaming of streets and removal of memorial plaques in the former Soviet Union (FSU). There are also municipal campaigns aimed to dismantle unwanted signs, and overwriting on posters. Finally, there are graffiti often presenting a dialogue or a polylogue of their creators (Pennycook 2010). 
As the field is developing, some studies extend investigations of LL to written texts inside public buildings and even private homes since various objects acquired for the household may also be multilingual (Aronin, \& O Laoire 2013). Inscriptions on monuments and memorials, which reveal the tension between national ideologies and competing memories are also studied as part of LL (Abousnnouga, \& Machin 2010). For the central theme of this issue an important aspect of LL research is strategies applied by immigrant communities in finding their niche in the economies of receiving countries and affirming their identity vis-à-vis their hosts in marking public space (Mustajoki, \& Protassova 2014; Woldemariam, \& Lanza 2015). Moreover, with the proliferation of information technologies, the virtual city as it emerges on the websites uploaded and administered by municipalities, commercial companies, interest groups and individuals serves as an extension of the physical city and forms an integral part of its LL (Fialkova, \& Yelenevskaya 2013: 73-78).

LL researchers commonly distinguish between top-down and bottom-up signage (see, e.g., Backhaus 2007; Ben-Rafael et al., 2006; Coupland 2010). The former refers to the signs issued by state or municipal authorities, while the latter are created by owners of private businesses. In multilingual countries the state may mandate which language/languages have to appear on every sign. Thus, the main document of Quebec language policy requires that traffic signs, commercial advertisements, and public signs and posters must be in French only (Backhaus 2007: 17). In Israel the marking of road signs is decreed by the Ministry of Transport and requires the use of Hebrew, Arabic and English. Bernard Spolsky observed that "top-down" and "bottom-up" dichotomy is incomplete if we don't take into account government regulation of both (Spolsky 2009: 28). Indeed, we have to consider whether public space is linguistically ordered and regulated by decrees of the central government or whether control in this domain is delegated to local authorities. In addition, it is worth looking into how strictly these regulations are observed and whether there are sanctions for violations. In fact, we can see that in some countries local authorities have become much more tolerant of unsanctioned writing in the city. A good example is contests of pavement drawings and creative graffiti held in various towns under auspices of municipalities (e.g., Berlin, Moscow, Tel Aviv). This and differences in the order of languages, size of font and (un)equivalence of texts on multilingual signs reveal official language policies, as well as practices following or subverting them. Bottom-up signs created by commercial companies and shop owners are often creative and ignore official guidelines. At the same time, Coupland remarks that commercial initiatives have their own "from above" qualities and adds that all LL texts are "deeply commodified and commodifying" (2010: 79). And this points to another important aspect of LL studies: tracing how language is used and manipulated in the symbolic economy of the city (Zukin, 1998), when the use of a prestigious language and cultural symbols of different linguistic groups are included in signs as a marketing strategy — not to inform but to impress and attract.

Although Israeli linguists were among the pioneers of LL research, most of the work done so far has been dedicated to the interaction of Hebrew, Arabic and English (Spolsky, \& Cooper 1991; Ben-Rafael et al 2006; Spolsky 2009). The only studies devoted to the 
functioning of immigrant languages in the LL of the country have been conducted by Ben Rafael, \& Ben Rafael, who analyzed French signs in the city of Netanya (2010), by Elias, and Greenspan in an essay about an advertising campaign targeting Russian speakers (2007), and by Fialkova 1999, who investigated the growing role of Russian in Israel's trade (1999) and the failure of the Ukrainian language to assume the same role (2007: 116-154).

This essay follows up on the latter study and on our joint work in urban anthropology (Yelenevskaya, \& Fialkova 2006; Fialkova, \& Yelenevskaya 2011; Fialkova, \& Yelenevskaya 2013: 23-82). In particular, we explore:

- How state agencies interpret the needs of ethnic minorities and respond to them as reflected in the LL;

- What LL tells us about integration of the Russian language into Israeli economy;

- What LL reveals about immigrants' interaction with the host society;

- How instrumental and symbolic functions of the language are reflected in the LL.

We will begin with a brief description of the linguistic situation in Israel and the status of Russian. Then we will discuss how the host society accommodates the needs of Russian-speaking community in dealing with state agencies and private companies. We will go on to explore which market niches based on intense language use are successfully exploited by the Russophones. Finally, we will show the commodification of Russian and Soviet cultural symbols as reflected in the LL. Throughout the article we will reflect on the interaction of political, ideological and economic factors in the marking of a multilingual city.

Recently, Israeli society has demonstrated a slightly more positive attitude to the immigrants' maintenance of their heritage languages. However, while proficiency in English is unequivocally considered to be a valuable commodity, proficiency in French, Spanish and Russian - languages of big immigrant groups is seldom viewed in these terms. Among Russian-speaking Israelis themselves the issue of language maintenance is primarily associated with preservation of cultural values, intergenerational and transnational family ties, and individual enrichment (Golan-Cook, \& Olshtain 2011; Kopeliovitch 2013; Zbenovich, \& Lerner 2013). According to the published studies and our own observations, language transfer to the young generations is less frequently viewed as a commodity or as a career-enhancing asset.

The discursive construction of public places as multilingual encourages multilingualism (Schwartz, \& Verschik 2013: 16-17). Moreover, the use of minority languages on the signs of government agencies and important commercial enterprises, as well as in the materials they publish on- and offline raise the status of minority languages and ascertain their social and economic value.

Material for analysis was drawn from three different sources:

- 300 pictures taken by the authors for this project;

- institutional and commercial websites;

- ethnographic notes taken during fieldwork.

Our ethnographic diaries include informal conversations with people in the streets, clerks in government offices, salespeople, business owners and their clients. Visiting various institutions we spent 30 - 40 minutes in each, observing interaction of employees with the customers and talking with them. We asked Hebrew-speaking clerks whether they found multilingual signs useful in serving clients and whether they had colleagues 
speaking immigrant languages that could help them to communicate with those clients who were unable to speak Hebrew and/or fill out necessary forms. We also talked to Russian-speaking clerks asking how often they had to use Russian in their work and whether it was approved of by their superiors. We were interested to know whether young people who grew up in Israel and were Hebrew-Russian bilinguals found Russian useful in looking for jobs and whether their oral and written skills were sufficient for the tasks they had to fulfill at work. The fieldwork was conducted in Haifa in the fall-winter of 2016. Haifa was chosen as one of the most Russian-language-friendly cities of Israel and because we have already documented its LL in the late 1990s and mid-2000s, so we were interested in changes that have occurred over time. For our various projects we have conducted participant observation for more than 20 years in such towns of Israel as Tel Aviv, Nazareth, Acre, Eilat, Netanya, and others. Our photo-archive contains over 1,000 pictures and the first documents were collected in mid-1990s.

\section{RUSSIAN ON THE LINGUISTIC MAP OF ISRAEL}

Language situation in Israel is an example par excellence of contradictions between language policies, language ideologies and language practices. A country with two official languages, Hebrew and Arabic, and at least 35 languages spoken in informal settings (Lewis et al. 2016) (2), it has a strong Hebrew hegemony supported by legislation (Deutch 2005). In the first decades of Israel's existence the traditional multilingualism of the diaspora Jews was suppressed and a total switch to Hebrew was imposed. The results of this subtractive linguistic policy led to a widespread ideological monolingualism (Spolsky 2001). While the policy of Hebrew hegemony contributed to its development in the domains it had not been used before, it had a political price of alienating Arabicspeaking citizens of Israel, harmed intergenerational ties, and had an economic price for those immigrants who were slow in acquiring Hebrew, and therefore suffered a deficiency on the job market.

The pressure to reject diaspora languages (e.g., Polish, Russian, Rumanian, etc.), including such Jewish languages as Yiddish, Judeo-Arabic and Ladino met with little resistance. Rigid language ideologies bred linguistic intolerance, which has not been overcome until now and is manifested in criticism of those new immigrants who continue speaking their home languages (Yelenevskaya, \& Fialkova 2005, v. 1, 150 - 154), conflicts at work (Yelenevskaya 2015: 202-203) and jokelore (Shifman, \& Katz 2005).

The only language that has been spared ideological rejection in various domains, including LL is English. First, despite all the state regulations, some of the English signage that was dominant in the years of the British mandate remained (Spolsky, \& Cooper 1991). English is regarded as the language of highest prestige, and its growing use meets no resistance in the population. This and the desire to develop tourism further expands the use of English in signage, a trend observed in many countries.

The arrival of over 1 million immigrants from the FSU in the 1990s has changed the linguistic balance in the country. The Israeli establishment had to make concessions to the "melting pot philosophy" of immigrants' absorption, and foster Russian, as a channel of information, education and culture to facilitate faster integration (Glinert 1995). Despite a high percentage of professionals among FSU immigrants, about two thirds failed to find jobs compatible with their education and professional experience (Remen- 
nick 2008: 168). Those who were enterprising and daring, launched their own businesses, thus giving birth to the Russian sector of Israeli economy.

Russian has become a third most spoken language of the country (3). It has no official status, however, unlike other immigrant languages, it is not restricted to home use and has penetrated virtually all spheres of public life. While the availability of services in Russian contributes to the country's openness to multilingualism and simplifies life for first-generation immigrants, in a sense, it also creates a vicious circle, decreasing motivation for some to learn Hebrew. According to the data of the Central Bureau of Statistics published in 2013, only 51\% of the FSU immigrants who settled down in the 1990s assess their Hebrew command as good or very good; $21 \%$ can hardly communicate in Hebrew; 19\% read with some difficulty and 39\% experience great difficulty or cannot read Hebrew at all (4).

Among members of the one-and-a-half and second generation immigrants, who still speak Russian, there are signs of attrition (Perotto, \& Niznik 2014) yet, there is considerable institutional support within the community facilitating language maintenance and contributing to a reverse language shift among the young in the families determined to preserve Russian. These are bilingual kindergartens, afternoon schools and various hobby groups in which instructors speak Russian. This heritage language support is beneficial for those young people who find that proficiency in Russian is an asset on the job market [fig. 1].

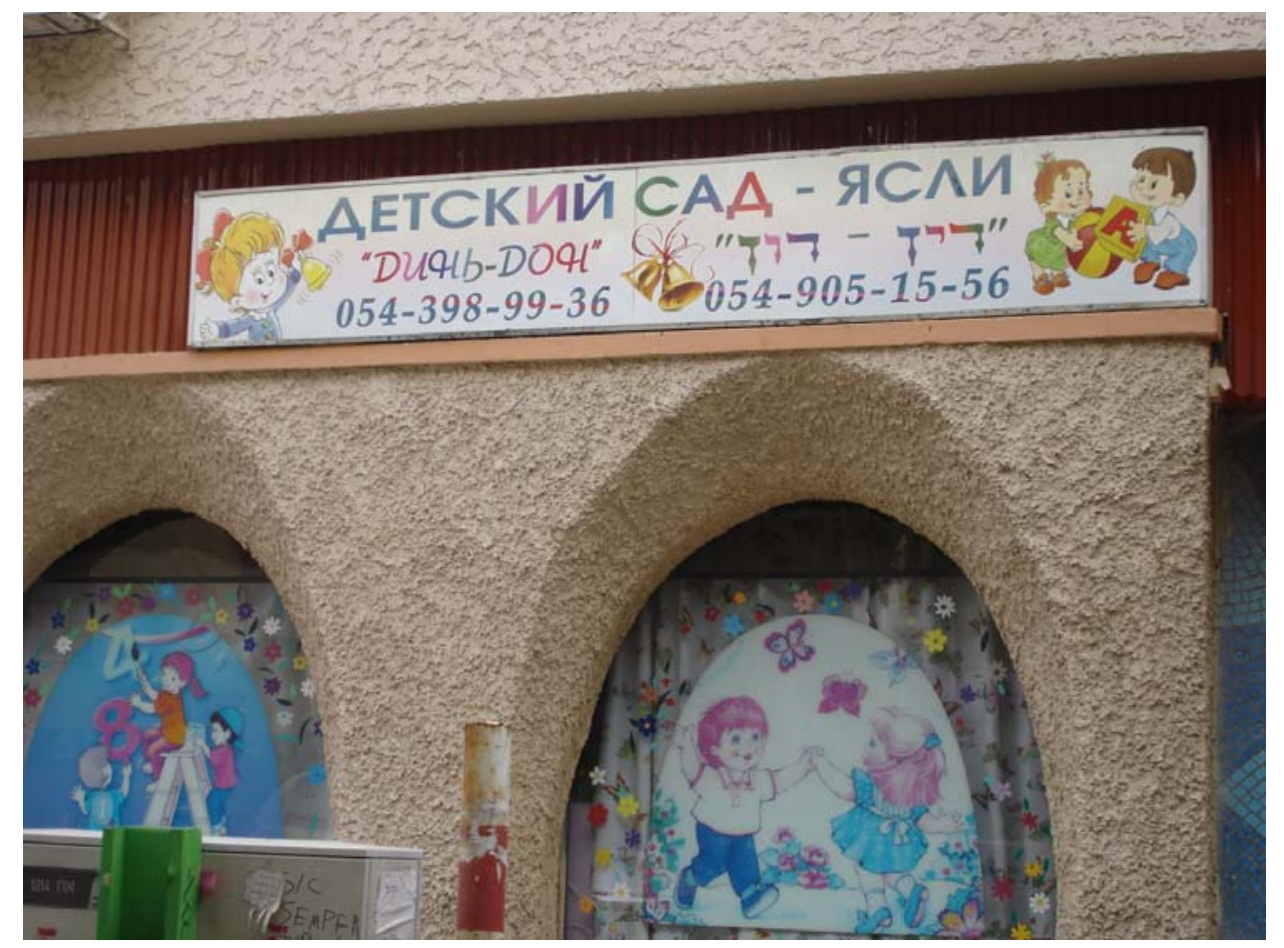

Figure 1. Bilingual Hebrew-Russian kindergartens are popular not only among newcomers but also among young parents who immigrated as young children or were born in Israel. The names Солнышко [Little Sun] Динь-Дон [Ding-Dong], Микки-Mayc [Mickey-Mouse], Вишенка [Little-Cherry] and others, using diminutive suffixes and alluding to children's fairy-tales and cartoons sound homely and inviting 
Although members of the host society generally refer to all the FSU immigrants as "Russians", the group is heterogeneous in terms of origin. According to the demographic data cited by Tolts, in the period when the majority of immigrants arrived (1989-2001), the three biggest groups came from the Russian Federation $(291,200)$, Ukraine (299,800), Central Asia (114,700) (2011: 6). Other sizeable groups arrived from Belorussia, Moldova, Transcaucasia and Baltic states [fig. 2]. Yet, Russian serves as the lingua franca for the entire community (cf. Kliuchnikova 2015) and is the only language enjoying institutional support (mass media, complementary education, professional retraining, etc.) Notably, even the crisis in Ukraine which divided the immigrants did not change the situation (Fialkova, \& Yelenevskaya 2015).

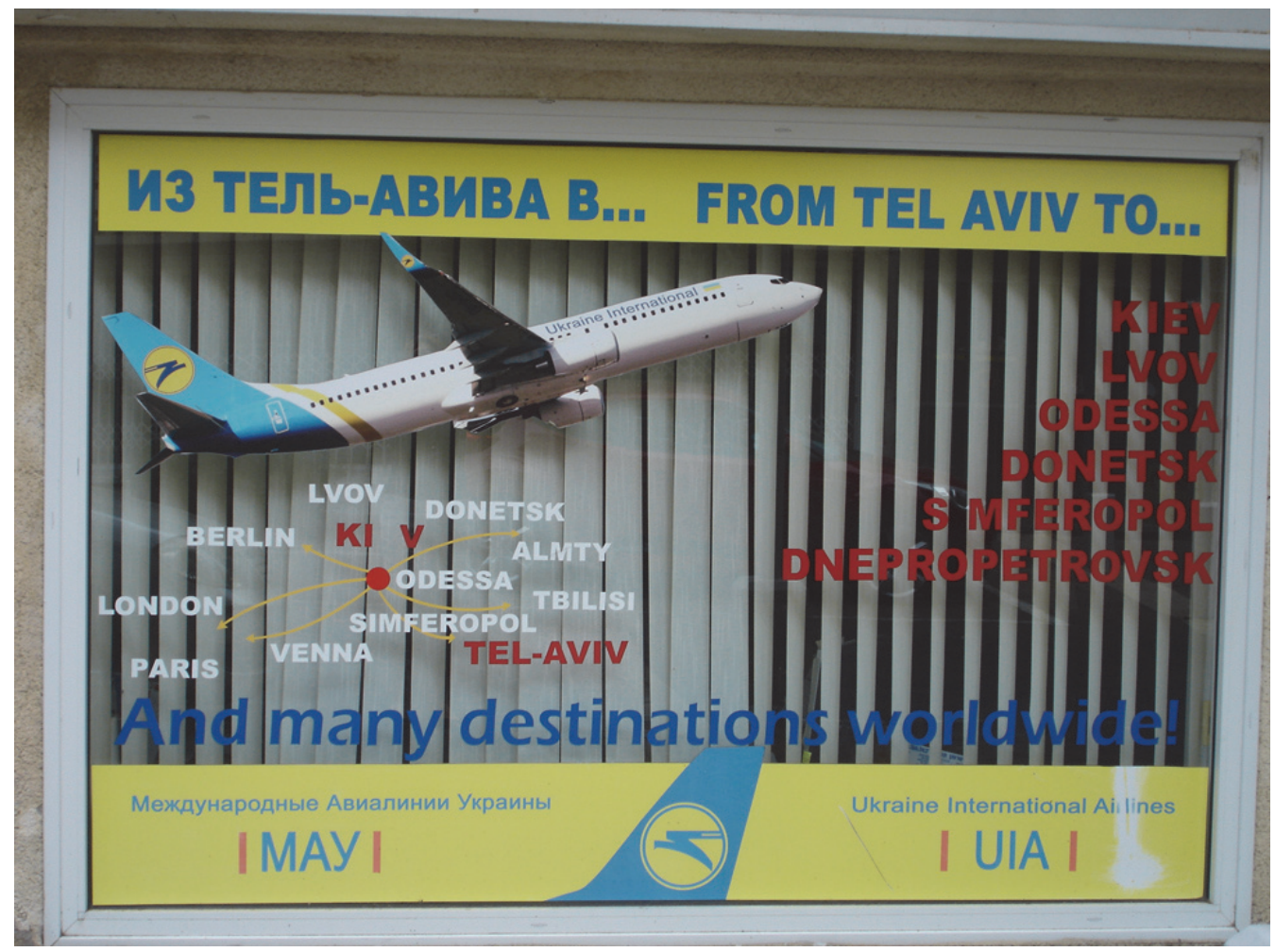

Figure 2. A travel agency advertising Ukrainian airlines uses the colors of the Ukrainian national flag in the design of its shop window, but the texts are in Russian and English

\section{RUSSIAN ON TOP-DOWN SIGNS: HOW THE STATE REACHES OUT TO NEW IMMIGRANTS}

In the project investigating personal narratives of ex-Soviets in Israel, one of the motifs in the interviews we conducted was newcomers' discomfort when they walked along the streets of their new towns which did not have comprehensible signs. Comparing themselves to the "mute and deaf" and their environment to the "language vacuum", our interviewees shared with us their feeling of insecurity and alienation (Yelenevskaya \& Fialkova 2005, v. 2: $110-156)$. The first to react to the needs of new arrivals were 
government institutions which had to process immigrants' documents and accommodate their first needs. Although the signs on the buildings of the local divisions of the Ministries of the Interior, Immigrants' Absorption, Education, etc., were in Hebrew, employees, veteran immigrants of the 1970s, found their previously unwanted linguistic resources in demand and would put up hand-written Russian announcements for new arrivals. Gradually, these were replaced by printed posters and were complemented by leaflets and booklets with relevant information in Russian. A case in point is the National Insurance Institute of Israel. The building it occupies in Haifa has only a Hebrew sign on the façade, but in the central hall visitors see notices in three languages: Hebrew, Arabic and Russian [fig. 3]. There is a 40-page booklet in these languages and in English, describing services provided by the institution, physical and email addresses, telephones and reception hours. All the forms to be filled out by the clients are only in Hebrew, but there are clerks speaking English, Arabic and Russian. Moreover, there are Russian-speaking volunteers who help visitors fill out the forms and act as interpreters, because multilingualism of the signs ends on the ground floor: the rest of the building is marked in Hebrew alone.

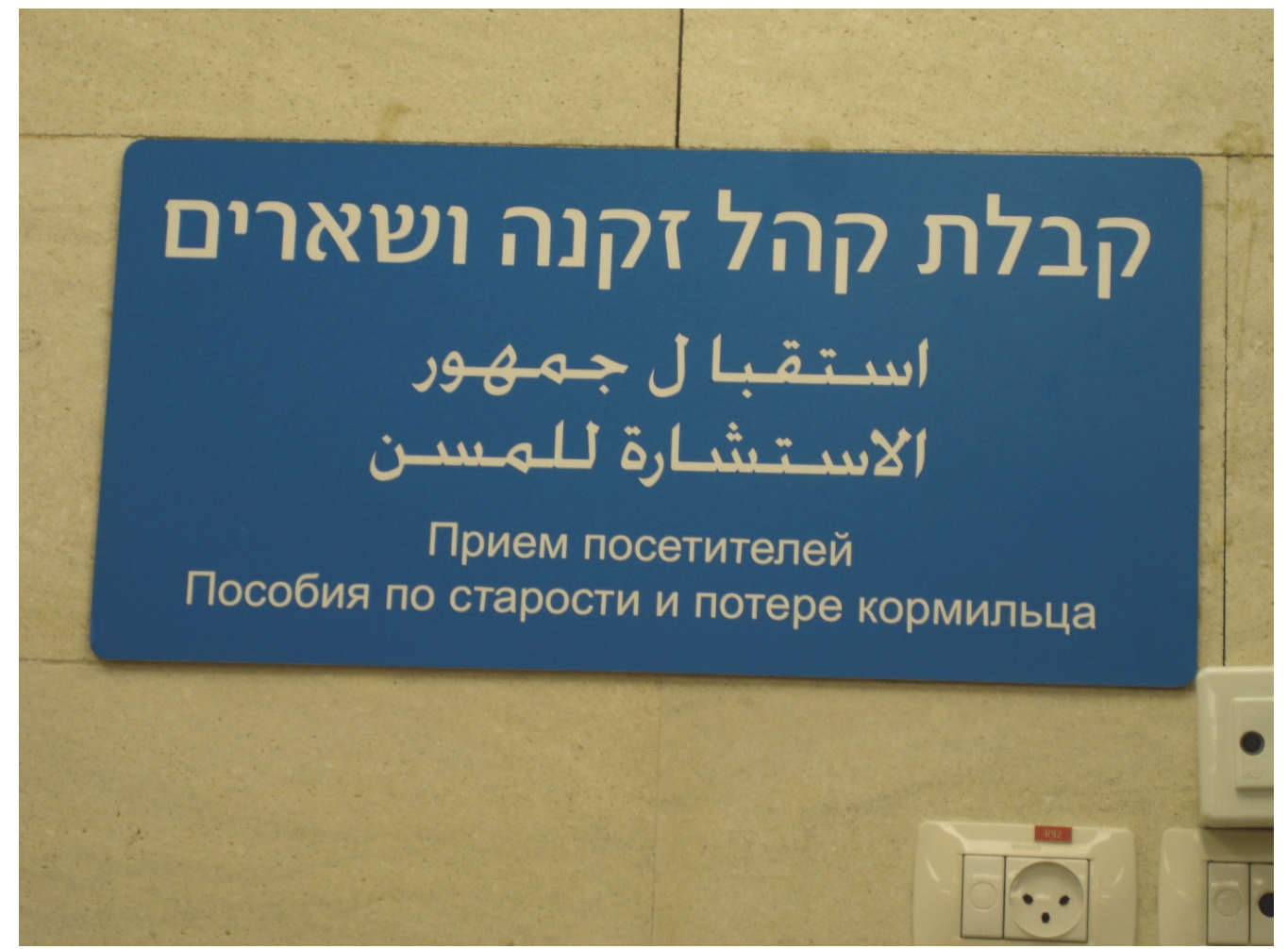

Figure 3. On trilingual signs in the entrance hall of the National Insurance Institute Hebrew texts dominate: they are the first in order and the size of their letters is twice as big as those in Arabic and Russian

When we made rounds of government institutions, utility companies, post offices, banks, clinics and communications providers in 2016, we found that their language policy is at least partially multilingual, although the use of different languages is unsystematic. 
Almost everywhere there are automata for getting numbers in line which "speak" Hebrew, Arabic, English and Russian. In most places we visited there were employees who could serve customers in Russian. Moreover, Hebrew- and Arabic-speaking clerks have learned Russian terms frequently used in their professional domain and insert them confidently while communicating with the customers whose Hebrew is limited.

We concentrated our fieldwork on post-offices and banks since these institutions are used by all the residents. In the six post offices we observed all the posters and announcements were in Hebrew. The only Hebrew-Arabic document displayed to the customers is a poster citing policies of the Israel Postal Authority; there is also a trilingual (Hebrew, English, Arabic) announcement that transactions exceeding 10,000 shekels require an ID. The only flier in Russian we found in one division announced a new postal service: parcel delivery from Israel to Moldova by sea. Even the smallest post offices have a screen with running advertising. When we were conducting our fieldwork there was just one announcement in Russian Hem долгам! [Say "no" to debts], informing Haifa residents about an end-of-the-year $40 \%$ discount for still unpaid municipal fines. At the same time, in all the post offices we heard clerks speak English to the clients, in three Arabic and in four Russian. The website of Israel Postal Authority is in four languages, including Russian (5). It provides information about services to private persons and businesses, prices, etc. The Hebrew page is the most comprehensive of all. When you press links on the Russian page they sometimes bring you to the Hebrew section and sometimes to the English one. An essay about the history of postal services in Israel and a list of new stamps, e.g., appear only in English.

Our visits to 10 branches of five biggest banks (6) showed that all the writing there is in Hebrew, with occasional insertion of English words and phrases, such as "business", "start-up", "gold", and so on, where English is used for its symbolic value rather than for providing information (Kelly-Holmes, 2005: 184). The only bilingual Hebrew-Arabic text on the walls of these banks is a warning that smoking is prohibited. The sign is massproduced and is found in many institutions. In one branch we found a leaflet in five languages (Hebrew, English, French, Russian, Amharic (7) and Arabic) alerting customers to the importance of understanding the actions they wish to perform in the bank and informing them that they are entitled to receive explanations in the language they understand. When we asked whether we could get explanations in Russian we were directed to a Russian-speaking clerk. There was also an opportunity to get explanations in English and Arabic, but not in Amharic or French. Among the branches we visited, in three there were no Russian-speaking employees. In one of them the clerk answering our questions said with a chuckle:

There used to be just one poor guy who spoke Russian but he quit. I mean, "poor" in a good sense. We all tormented him with questions, asking to act as our interpreter.

In one branch we found a glossy multilingual booklet published by the Bank of Israel when a new 200-shekel banknote was issued. It contains information about the Israeli poet Nathan Alterman, who is represented on these bills and a description of anti-counterfeiting security features, as well as features for the blind and visually impaired. Notably, one cover page of the booklet is in Hebrew and Arabic, both of which have right-to-left writing systems; the other is for those who read from left-to-right: English, Russian and Amharic. 
Bank clerks we talked to were primarily eager to help us, but to our surprise, despite the banks' policy of encouraging clients to use online services, they were ignorant about these internet resources and did not know whether their banks' websites were multilingual. In fact, they are, and virtual banking is much more accommodating to speakers of Arabic, English, and Russian than its physical counterpart. The most detailed Russian section is offered by the website of Bank Leumi. Besides information about online and offline services it offers technical support in Russian, describes privileges of virtual banking and posts information about new saving investment programs (8). Another bank, Ben-Leumi, introduces its work with Russian speakers as эксклюзивнье услуги для наших русскоговорящих клиентов [exclusive services for our Russian-speaking clients]. Along with information about various services it lists 19 branches where clients can be served in Russian, indicating that these branches are located in the areas of high concentration of Russian speakers. The website also mentions that the bank's call center has Russian-speaking operators. Notably, below the bank's logo it says: ценим вam ycnex [we value your success] (9). Besides targeting residents of Israel, the banks whose websites we analyzed cater to international Russian-speaking clients. The largest Israeli bank, Hapoalim, e.g., has sections for domestic clients in Hebrew, Arabic, and Russian, while its international section is in Hebrew, English, Russian and Spanish (10).

Like in many technologically advanced countries, Israeli state-run institutions and big commercial companies encourage residents to reduce visits to their offices to the minimum and obtain relevant information online or on the phone. As a rule, call centers start their extended menus with a language choice, and Russian is one of the languages offered. Sometimes, however, after a lengthy waiting period a caller who has chosen Russian is connected to a Hebrew-speaking operator. According to our informants employed as operators of communications providers, their ability to talk to customers in Russian and English was an important factor when they were hired, although their proficiency in these languages was not tested.

Some municipalities have also become accommodating to linguistic minorities. In order to compare Haifa to other towns we studied websites of 11 municipalities, choosing localities with big Russian-speaking communities (see the table below).

Table

Languages on Municipal Websites

\begin{tabular}{|l|l|}
\hline \multicolumn{1}{|c|}{ City } & \multicolumn{1}{c|}{ Language sections } \\
\hline Jerusalem & Hebrew, Arabic, English \\
\hline Tel Aviv & Hebrew, Arabic, English \\
\hline Haifa & Hebrew, Arabic, English \\
\hline Netanya & Hebrew, Arabic, English, French, Russian \\
\hline Ashdod & Hebrew, English, French, Russian Spanish, \\
\hline Ashkelon & Hebrew, Arabic, English \\
\hline Beer Sheba & Hebrew, English \\
\hline Karmiel & Hebrew, English \\
\hline Upper Nazareth & Hebrew, English, Russian \\
\hline Arad & Hebrew \\
\hline Ariel & Hebrew, English \\
\hline
\end{tabular}


As we see, only one website is monolingual. Notably, not all the municipalities included the second official language, Arabic, and not a single one has any information in Amharic. None of the websites has the same amount of information in all the languages. Materials in Hebrew are most detailed, and all the forms needed to be filled out to solve various issues with the municipality and which can be downloaded by the residents appear only in Hebrew. No instructions for filling them out are provided. All the websites talk about the beauty of the nature around their town, advertise cultural events and new development projects. There are also rubrics about educational resources and affordable housing. The only municipal website that gives an idea of how immigrant community life is organized is of Upper Nazareth. It does not appear in the Hebrew or English sections but only in Russian and invites residents to join various clubs and hobby groups. These are run separately for different ethnic communities, e.g.:

- Folk dances of the Caucasus for children

- Folk dances of the Caucasus for adults

- Women's club for immigrants from South America

- The club of the Ethiopian community

- "Bringing hearts together" — the club of Yiddish lovers

- Veterans' choir Ha-Tikva [The Dream] (11).

It is not clear how a page in Russian can help Ethiopian immigrants obtain information about quality leisure activities for their community, but the quoted list of events reflects a persistent feature of Israeli life: immigrants from different backgrounds study, work and do business together but they still prefer to socialize among co-ethnics.

Another interesting feature of the municipality sites is that seeking to attract new immigrants who can give an impetus to the economic life of the area they provide information about business and investment opportunities in their town. From our previous projects we know that municipal and informal city sites are carefully studied by wouldbe-immigrants who actively participate in city discussion forums in order to check with co-ethnics various immigration issues and compare to newcomers in different towns (Fialkova \& Yelenevskaya 2013: 23-82). This trust in personal networks rather than in officials and official sources of information is typical of our contemporaries in general and it is particularly common among people brought up in the countries where economies of favors rule.

Haifa municipality, which is more open to the Russian community life than many other local authorities, does not have Russian on its website or Facebook page (12). Yet internet search for Haifa Municipality in Cyrillic brings users to several websites providing information about various city institutions, including municipalities. One of them is Isracity.com, a non-profit website which was launched in 2003 and gives information in Russian about 13 Israeli towns. Another one is a commercial site Heдвижимость Израиля [Real estate in Israel], providing information about 47 localities. Both of them have Haifa pages. These websites cater to the residents of Israel, tourists and potential immigrants, explaining the function of government institutions and services rendered to the public and posting contact information. The names of the services 
are sometimes given only in Russian, sometimes both in Russian and in Hebrew but in Cyrillic transliteration:

Пособие по безработице и для сверхсрочников (автала и милуим)

[unemployment benefits and reserve service aid]

Производственные травмы (нивга ба-авода) [occupational injuries] (13),

and sometimes only in transliterated Hebrew:

мас ахнаса [income tax], тел. ..., факс ... [tel., fax]

ма'ам [VAT]: тел. ..., факс ...

мисуй мекаркаин [real estate taxation]: тел. ..., факс ... (14)

Besides help with mundane issues, these sites post telephones of various emergency services, including hot-lines giving instructions as to how to behave in case the users' city is bombed. This type of information in one's mother tongue is particularly important for newcomers who are not used to harsh realities of the country that is forever on the alert for terrorist and missile attacks.

In fact, doing fieldwork we paid special attention to the signs notifying residents of dangers. These also show inconsistency in language policies: notifications about high voltage appear in Hebrew, Arabic and English [fig. 4]; warnings about the danger of swimming on unguarded beaches are in four languages, including Russian (FSU immigrants and Russian tourists are known to jump into the sea in any weather in winter); instructions how to use defibrillators, which public institutions with at least 500 daily visitors must install in easily accessible places, are in five languages and include not only Russian, but also Amharic [fig. 5].

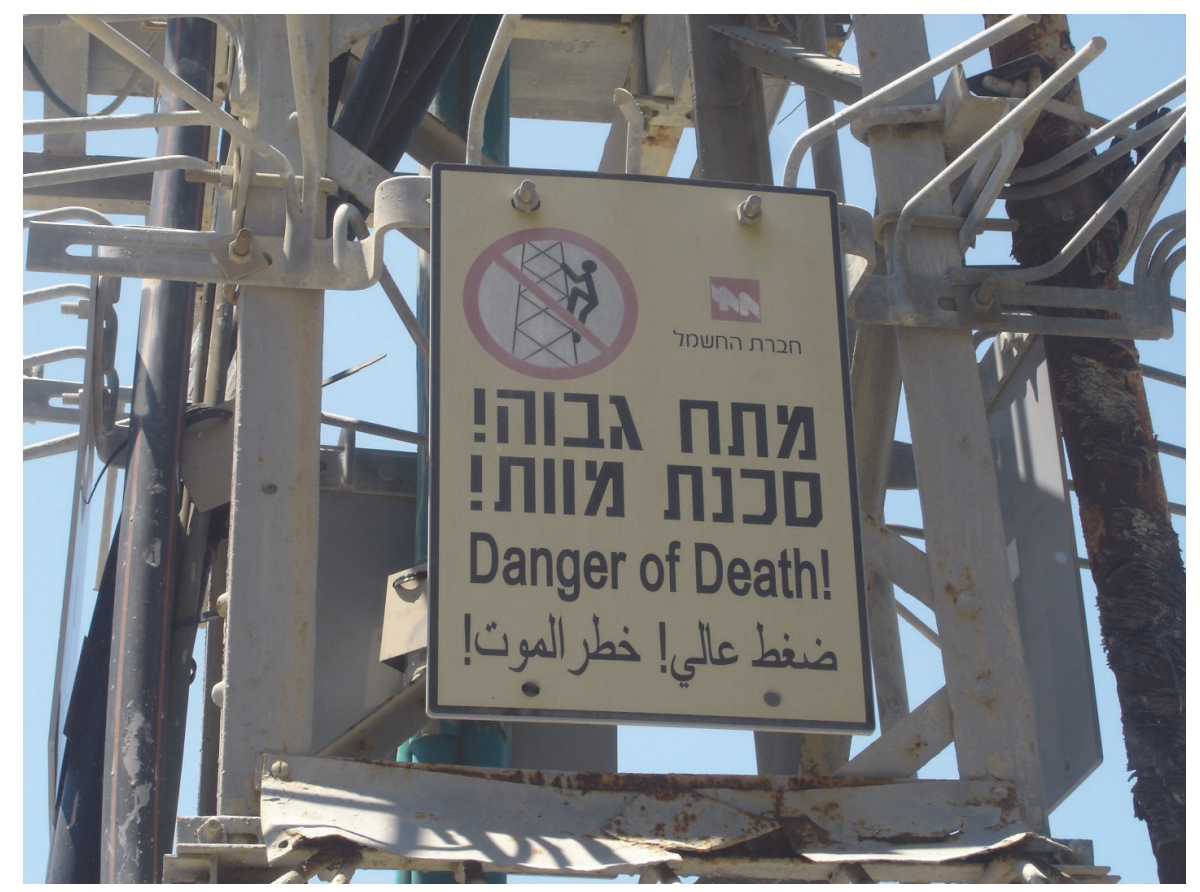

Figure 4. The logic behind the choice of languages on top-down sides is not always transparent. Could it be that some bureaucrat decided that risks are language-dependent? 


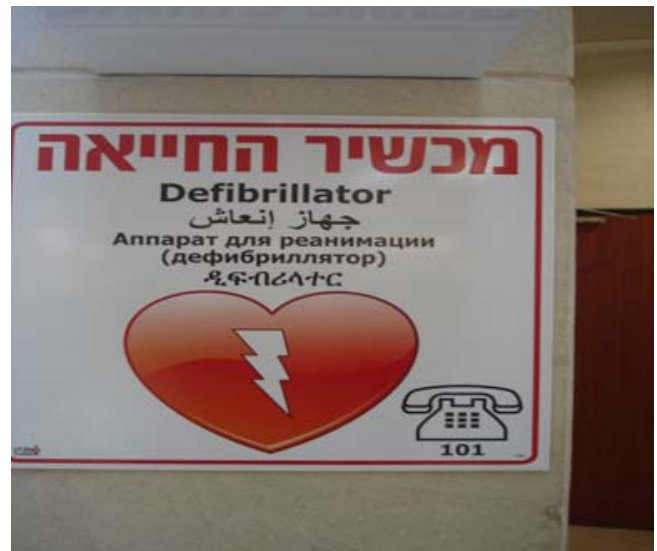

Figure 5. A defibrillator is always placed in a visible and easily accessible place. Each organization that is obliged to have it is also required to send some employees to a first-aid course to learn to use it. Nevertheless, instructions for its use appear in five languages

\section{BOTTOM-UP SIGNS IN RUSSIAN AND THEIR GEOGRAPHY}

Our fieldwork conducted in Haifa in three different periods of time (end of the 1990s, 2010 and 2016) shows that the diversity of businesses carrying Russian text on their signs and on posters and announcements inside buildings has increased, but their geographic distribution in the ethnically and socially stratified town has undergone few changes (Fialkova, \& Yelenevskaya 2011). In upscale residential areas on the top of Mount Carmel, which are highly valued not only because of a better quality of housing and quiet but also because they have more greenery and are better protected from the heat in summer, there are virtually no Russian signs.

As the streets go down Mount Carmel slopes and get closer to the sea, apartments become more affordable and one can notice that Hebrew advertisements on notice boards begin to alternate with Russian ones and some of the grocery stores carry Russian signs. Known in common parlance as русские магазины [Russian stores], many of them are owned by veteran Israelis of various origin, including Arab citizens of Israel. The signs over these shops are not necessarily in Russian. Thus two big chains of non-kosher supermarkets that have a wide selection of goods imported from the FSU have Hebrew names: Maadaney Rosman [Rosman delicacies] and Keshet Taamim [A rainbow of tastes]. These stores are true sites of glocalization of food production [fig. 6]. One can see jars with traditional Caucasian sauce аджика [spicy pepper-tomato-garlic sauce] produced in Germany, мармелад вишневый в черном шоколаде [cherry-flavored jelly coated in dark chocolate] imported from Austria and огуризы маринованье [pickled cucumbers] from Poland. Untouched by political animosities or sanctions, mash mallows from St. Petersburg are displayed next to chocolates from Kyiv and Riga. The labels demonstrate all the corners of the FSU, and Russian serves as a lingua franca of this global food market. In addition, all the labels include Hebrew descriptions of the products (for detailed analysis of precision/deviations of translation in the language of labels see Fialkova, 1999). The price tags are Russian-Hebrew bilingual, but the order of languages and the size of the font on them vary from one store to another. Notably, even if these shops are in Arab ownership, there is virtually no Arabic on the printed texts, though Arabic speakers frequent them. In residential areas one can also see playbills advertising 
shows of touring Russian companies and artists, and community events, such as New Year celebrations, the annual festival of documentary movies in Russian, КинОле, КВН contests (15), and others [fig. 7]. There are also Russian or bilingual Hebrew-Russian ads of various hobby groups and classes on the notice boards of community centers, on fences and on telephone posts [fig. 8]. In affluent residential areas even these signs in Russian are rare.

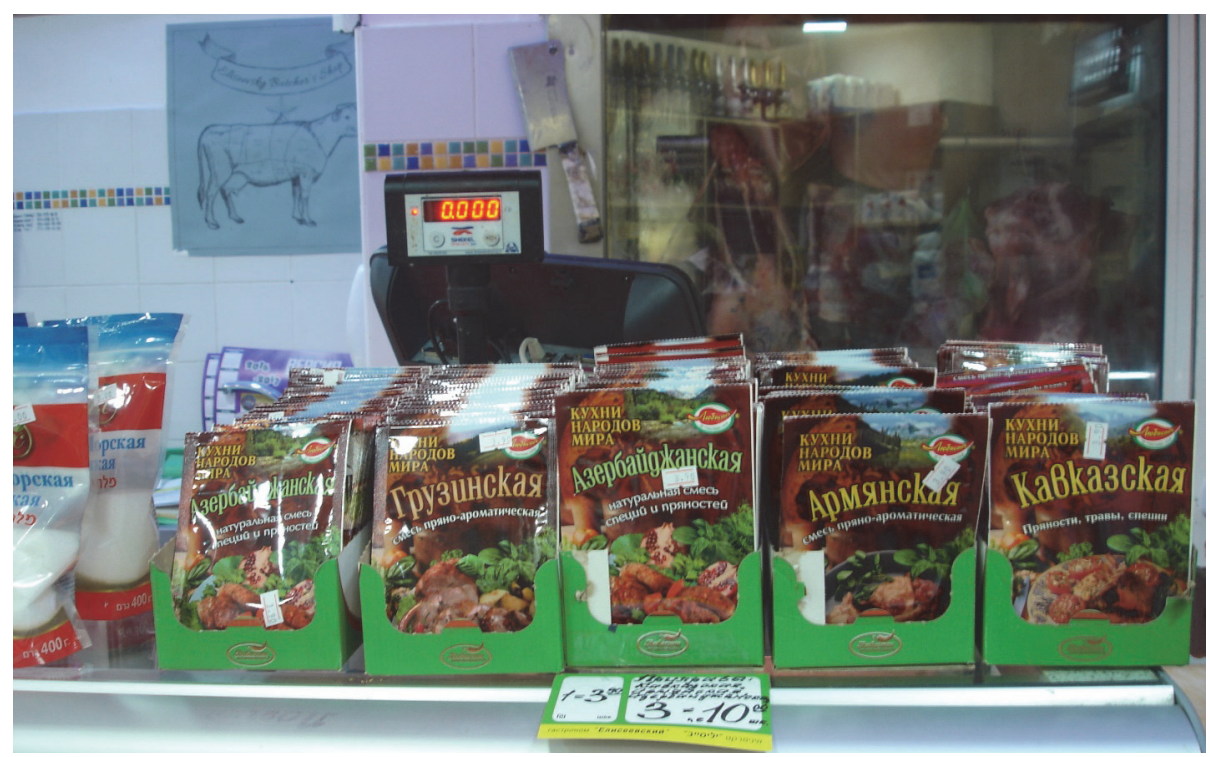

Figure 6. This spice collection in a "Russian" grocery store puts together flavors favored in various areas of the Caucasus, but the dominant language on the packets is Russian

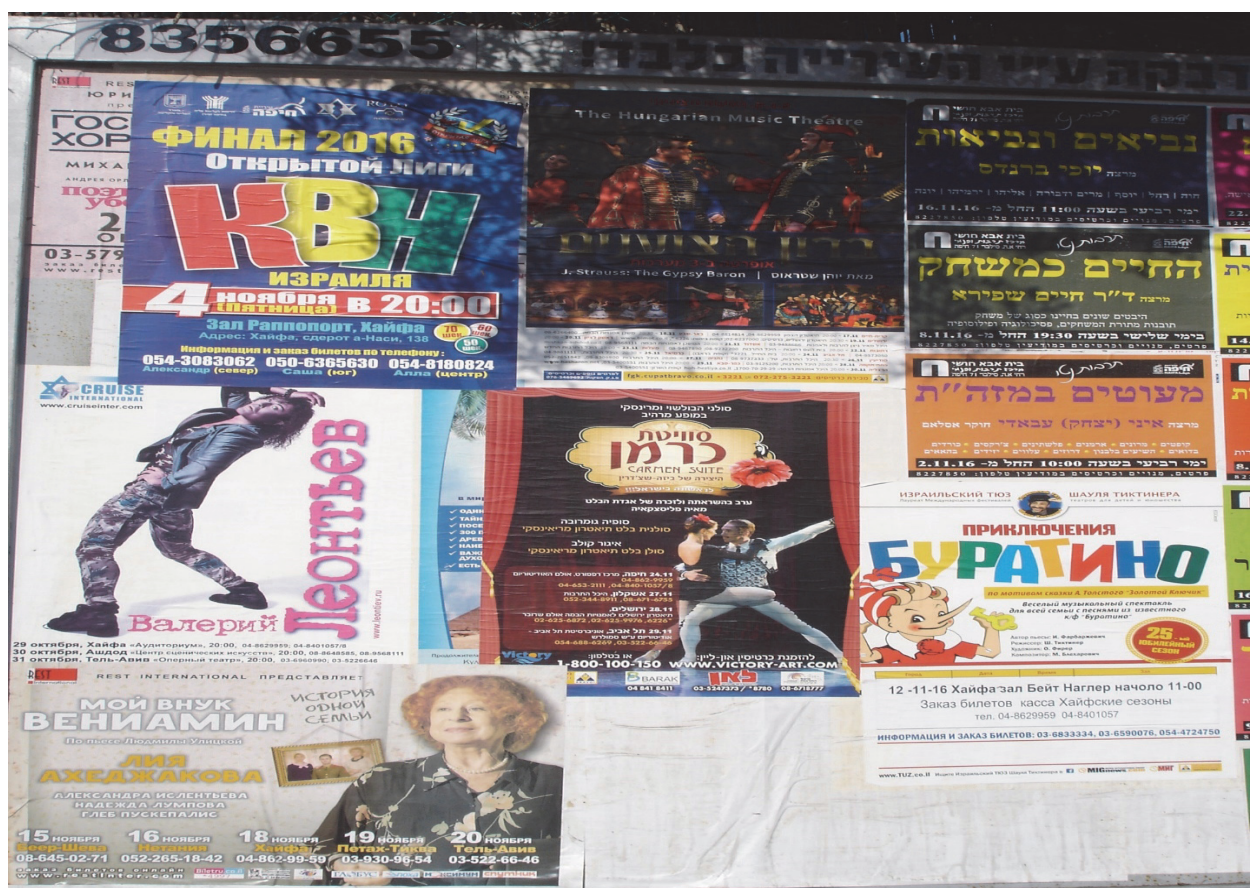

Figure 7. The posters of visiting Russian actors and musicians are placed next to announcements of community events, such as the final KVN game of the Open League of Israel 


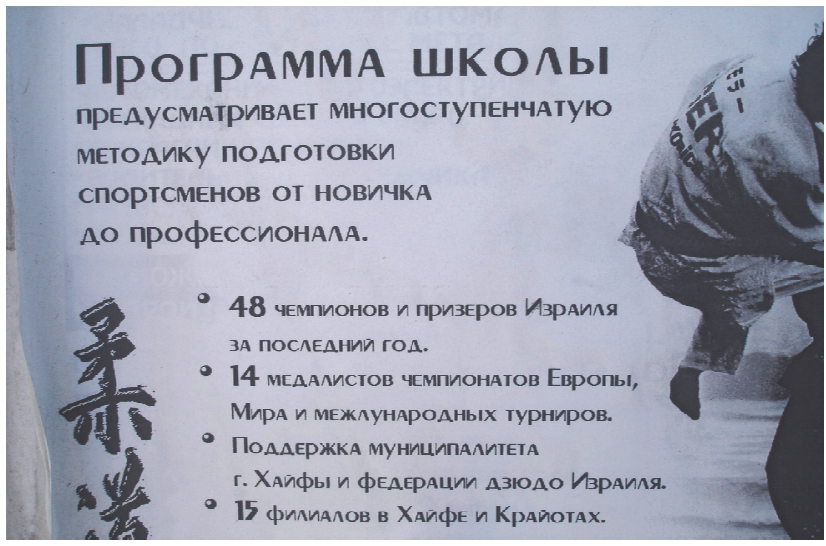

Figure 8. Precise body language is essential in sports; for advertising judo-lessons Russian is the language of choice on this poster. Hieroglyphs on the left were probably added for authenticity. No place on the ad was left for Hebrew, Arabic or English

There are also few traces of Russian presence in the industrial park where research branches of hi-tech companies are located, or on the campuses of Haifa University and the Technion-Israel Institute of Technology, although Russian-speaking Israelis make a high proportion among students and high-tech professionals. The only printed poster with a Russian text on the campus of the Technion-IIT we documented was a poster in Hebrew, English, Russian and Arabic explaining to victims of sexual harassment who to turn to for help. On the other hand, the concentration of English signs on the campuses is quite high, including announcements of conferences and seminars, and ads offering English tutoring and editing. This is compatible with the trend in other immigrant-receiving countries: professional integration into a job market requires high proficiency in the language of the host country and English. It was a lack of English proficiency that hampered re-integration of many Soviet-trained professionals, immigrants of the 1990s (Kheimets, \& Epstein 2001.)

Like twenty years earlier, when we began documenting linguistic landscape, the concentration of Russian signs and their diversity is highest in the old business center of the city known as Hadar. Following Ben-Rafael et al. 2006, we divided bottom-up signs into three main categories: professional (legal, medical, educational), commercial (food, clothing, household goods, furniture, etc.) and services (real estate, money transfer, translation, manpower agencies, etc.). In this essay we will concentrate on three subcategories that are heavily dependent on language use.

Bookstores. The repertoire of Haifa bookstores is diverse and customers can find Russian and world classics, phantasy and thrillers, and books for children. Big shops like Дон Kихот [Don Quixote], Дом книги [House of Books] [fig. 9] and Москва [Moscow] sell fiction and non-fiction, e.g., encyclopedias, dictionaries, guidebooks, cook books, etc. (cf. Khvorostyanova, and Elias, 2008: 320-322.) Most of the books are imported from Russia, but one can also find Russian-language Israeli publishers, such as Gesharim [bridges], Иврус [HebRus], Beseder Ltd.[O.k. Ltd.], Лира [Lyre], Спутник [Satellite] and some others (see Yuniverg 2015 about the rise of Russian-language publishing in Israel). The shop assistants whom we asked about interests of their clients and their age told us that books for children are always in high demand. There is an increasing interest in religious and esoteric literature, as well as Hebrew-Russian, Russian-Hebrew dic- 
tionaries targeting different professional domains for those who are learning a new trade or are retraining. Although booksellers we interviewed tried to sound optimistic and assure us that reading conventional paper books has again become fashionable among the young, the appearance of the bookshops suggested a slump. The crisis caused by electronic publishing hit all the bookstores in the country, and some closed down. Those that survived had to expand their repertoire to selling souvenirs. At the same time, some souvenir shops have begun to sell books, although their choice is limited to "easy reading".

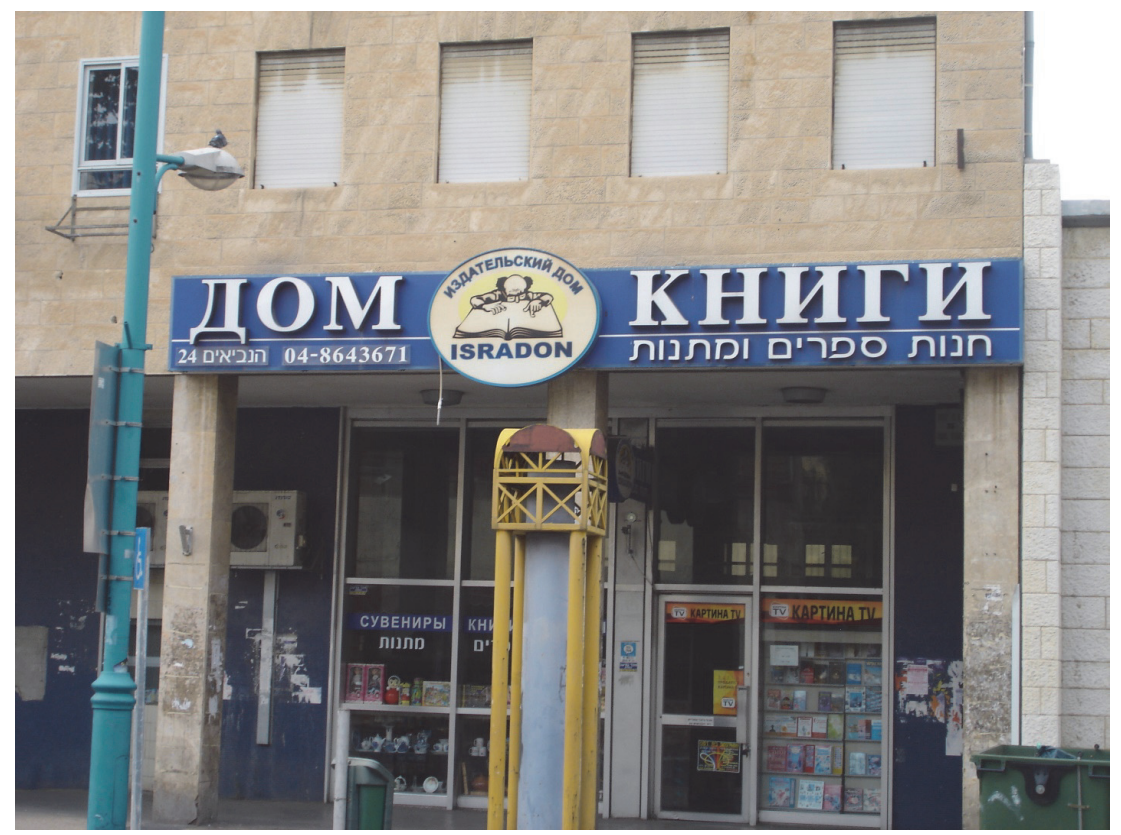

Figure 9. This bookstore bears the same name as the central bookstore of St. Petersburg, "The House of Books". It is affiliated with a publishing house and a cable TV company. Besides books of different genres it sells various souvenirs ranging from Gzhel' dishes and vases to humorous car stickers

December is the busiest season for Russian bookstores since they sell plastic Christmas trees and decorations for them. During this period Russian bookstores compete with Arab-owned stores catering to Christians. The Jewish New Year is in September and the attachment of Russian-speaking Israelis to the New Year celebration on the $31^{\text {st }}$ of December was completely misunderstood by Israeli society. Members of the lay public did not realize that it was a secular holiday in the immigrants' home countries and viewed the tradition and rituals associated with it as proof of immigrants' belonging to Christianity and therefore betrayal of their Jewishness (Fialkova, \& Yelenevskaya 2013a). The launching of a Haifa festival "Holiday of Holidays" held in December as a joint celebration of the festivals of the three religions prevalent in the city (Jewish Hanukkah, Christmas and Muslim Ramadan) increased the acceptance of celebrating what is called in Israel "a secular New Year" and gave a boost to "end of a year" gift sales and New-Year celebration advertising, much of which is in Russian (Yelenevskaya, $\&$ Fialkova 2012) [fig. 10]. The right to celebrate this secular holiday without inhibi- 
tions has become part of the agenda of young Russian speakers, one-and-a-half generation immigrants, who seek to assert their "Russian-Israeli" identity and coined a Hebrew neologism novigod as a marker of a new Israeli reality.

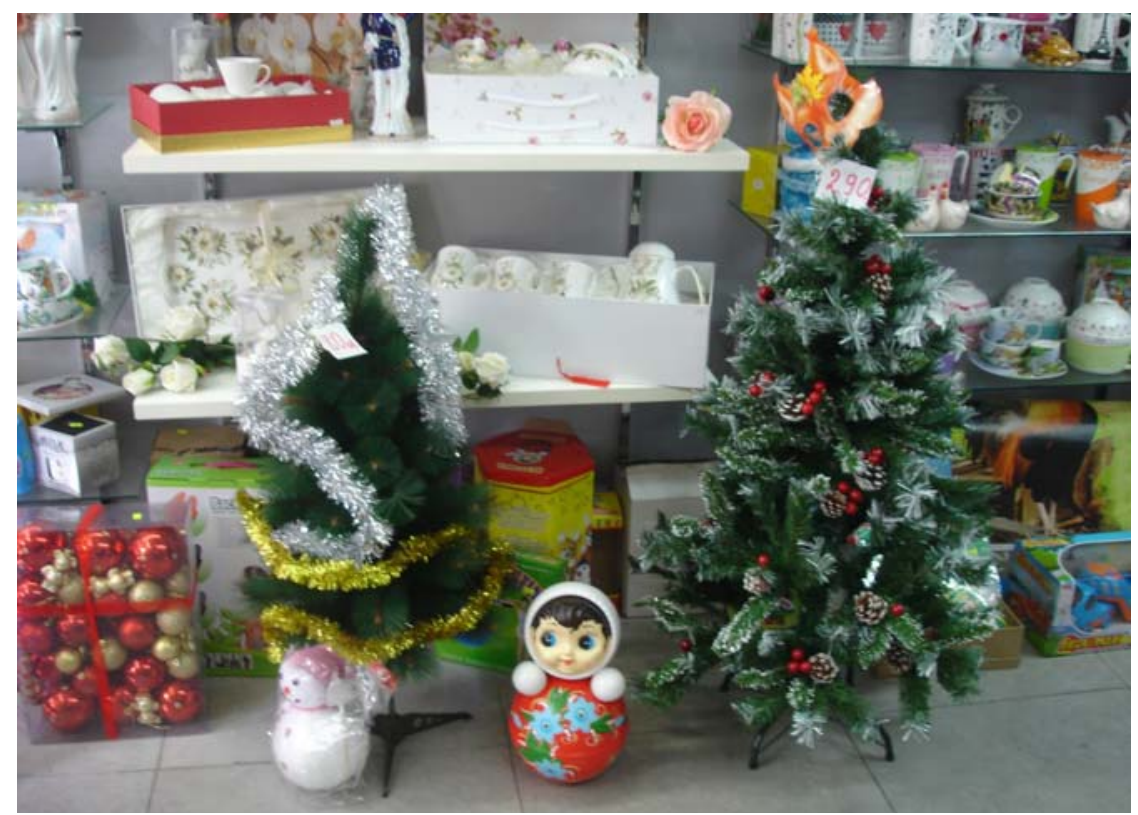

Figure 10. A New-Year sales marathon brings numerous Russian speakers to the stores selling New-Year paraphernalia. Even though most of the decorations for fir-trees are made in China, they have leaflets with Russian text

In spring, Russian bookstores participate in the Israeli book fair. In addition, they sell books in the intermission of Russian shows in theaters. Theater companies and musicians from Russia are frequent visitors to Israel. According to the Russian bookstore staff we spoke to during performances, theater goers and their clients are the same people, and there are more of them in theater foyers than they can ever dream of seeing in their stores.

Travel Agencies. Russian travel agencies are long-established businesses. Agreements about abolition of visa requirements with Russia (2008), Ukraine (2011) and Belorussia (2015) have boosted the popularity of Israel as a tourist destination in these countries. According to the Israel Central Bureau of Statistics, with 450,000 visitors, Russia was the second on the list of countries serving as the origin for the largest numbers of tourists to Israel in 2015, while Ukraine occupied the sixth position (16). Agencies providing tours in Russian sprang up already in the early 1990s when ex-Soviets finally had an opportunity to travel abroad. No wonder that one of the first Russian agencies in Haifa was called Путешествуем без границ [Traveling without borders], reflecting the excitement of people who had never crossed borders before immigration. Russianspeaking but Israeli trained guides, expanded on the standard repertoire of Israeli package tours. They developed routes that are of special interest to FSU visitors, such as Русский Иерусалим [Russian Jerusalem], Иерусалим Булгакова [Bulgakov's Jerusalem], Иерусалим православный [Russian orthodox Jerusalem]. They also included in their tours of other Israeli cities memorial places linked to Russian presence in Israel, such as Rus- 
sian Orthodox churches, Moskovia, Russian pilgrim shelter in Nazareth, and places familiar from Liudmila Ulitskaia's novel "Daniel Stein, Interpreter" in Haifa. But tourism in Israel depends on the security situation. Terrorist attacks and military operations in the Gaza strip slash foreign tourism. Yet, the Russian tourist niche managed to survive even in the hardest period of the second Palestinian uprising (Al Aqsa Intifada, 2000 -2005) by developing routes for domestic clients. Immigrants whose socio-economic situation stabilizes can satisfy their curiosity about their new home-country. Ads posted by Russian-speaking guides and agencies offer tours off the beaten track and bring together the landscapes and history of Israel and the Russian cultural background of their clients. The names of these tours Едем на крайний север [Traveling to the Far North], По Галилее... с Марком Твеном [In Galilee... with Mark Twain], Я знаю - город будет! [I know the city will come!], В гостях у дедушки Хатиба, тропинка специий и приправ, [Visiting grandpa Khatib, along a path of herbs and spices] and others, testify that Russian-speaking immigrants are actively domesticating their new home country. Whether using V. Mayakovsky's quotation which has become a speech cliché, or alluding to the barren and icy Arctic regions, which have little similarity with the lush greenery of Israel's north, Russian tourist business relies on the immigrants' background knowledge and adds a humorous touch to the advertised tours.

One other type of tours offered by Russian travel agencies is called wedding tours. Since there is no civil marriage, couples in which one or both are not Halachic Jews cannot get married in Israel. There are also Jewish couples who oppose religious marriage. Quick on the uptake, businessmen made arrangements in Cyprus, Georgia, Czech Republic, Bulgaria, Paraguay, etc., and some Russian travel agencies offer the service of arranging all the necessary formalities for registering marriage abroad combined with accommodation, a "romantic dinner" and a choice of entertainment for an express honeymoon, sometimes taking just a long weekend [fig. 11].

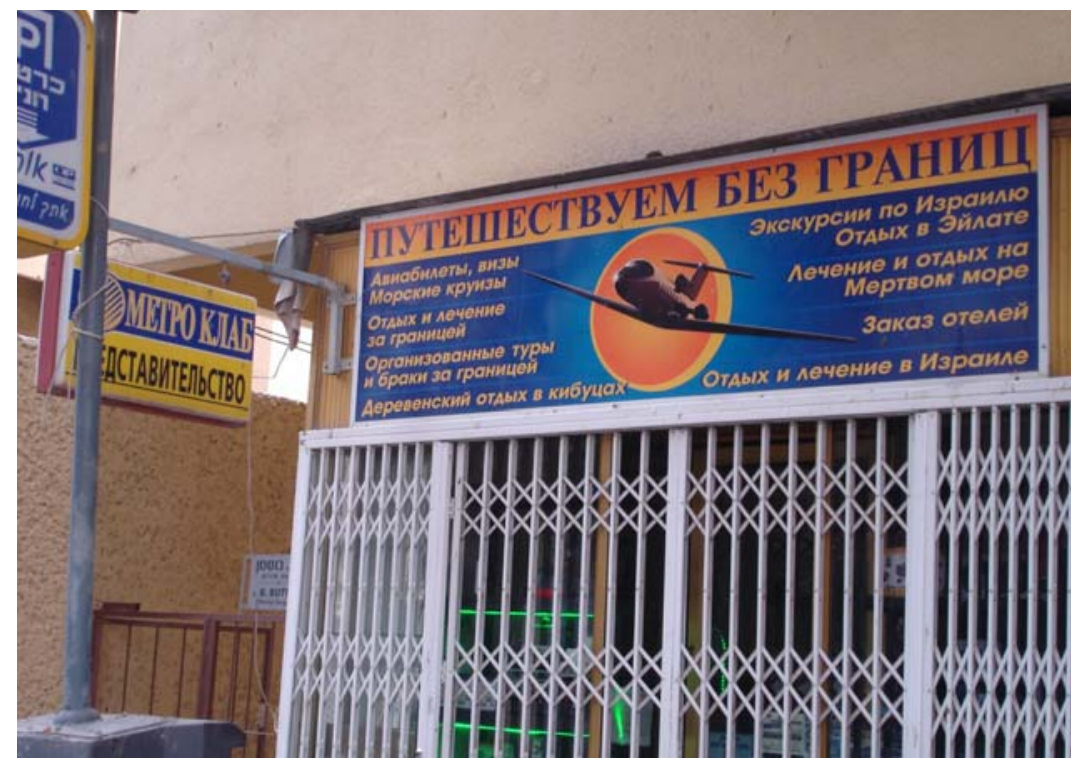

Figure 11. Although many people today book and organize their trips online without professional help, Russian travel agencies are in demand offering Russian-language guided tours both in Israel and abroad 
Law offices. Legal language is among the hardest registers for laypeople to master even in their mother tongue, let alone in a foreign language. Russian translators and interpreters were in high demand in Israeli law offices in the early 1990s, and today many lawyers specialize in offering legal help to FSU immigrants. Notably, among them are Arabs and Druze, graduates of Soviet universities. Services in demand are legalization of documents issued in the FSU, protection from deportation, and helping fourth-generation Jews prove their right to immigrate to Israel [fig. 12]. Some lawyers have created multi-profile law firms catering to the needs of individual clients and businesses in various spheres. The signs of the lawyers' offices bear their names and services rendered. The signs of Russian-speaking lawyers are primarily Russian-Hebrew bilingual but the list of services in Russian sometimes includes transliterated Hebrew legalese [fig. 13]. Like their other colleagues, Russian-speaking lawyers have websites. The information they put on the main page in Russian usually includes the length of work in Israel, serving as confirmation of experience and success, ties with law firms in the FSU, and language command, primarily, Ukrainian and English in addition to Hebrew and Russian. Some advertise "perfect knowledge", others are less arrogant:

Я владею английским и самостоятельно совершенствую русский язык, чтобы наше общение стало более доверительным, а значит и более плодотворным [I am proficient in English and I am perfecting Russian on my own in order to increase our mutual trust and consequently, make our communication more effective] (17).

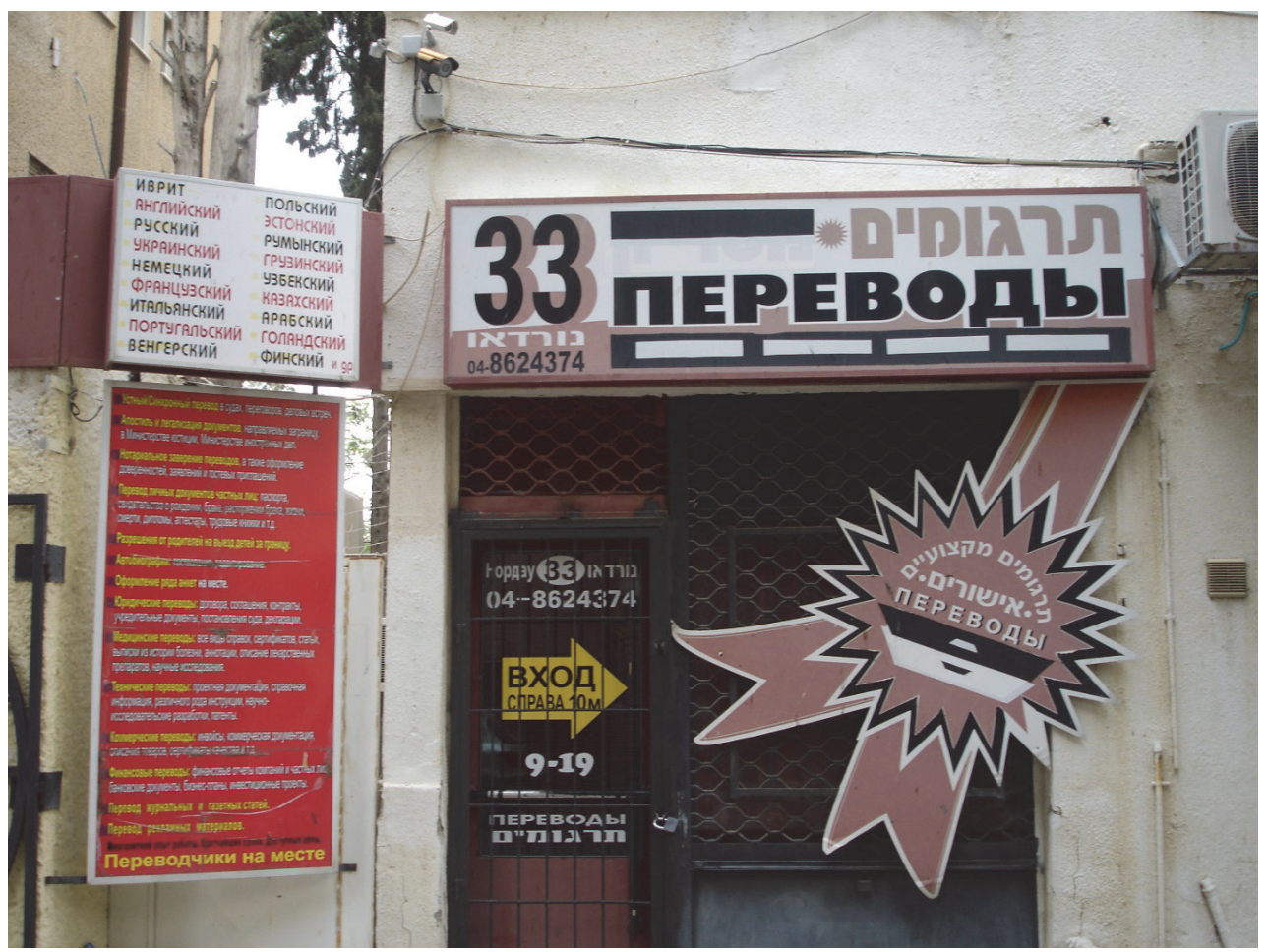

Figure 12. Those new immigrants who have to legalize their papers to obtain citizenship often need translators' and interpreters' services. This company offers translation from/to 18 languages, including Russian, Ukrainian, Estonian, Uzbek and Kazakh, but the signs outside and inside the office are only in Hebrew and Russian 


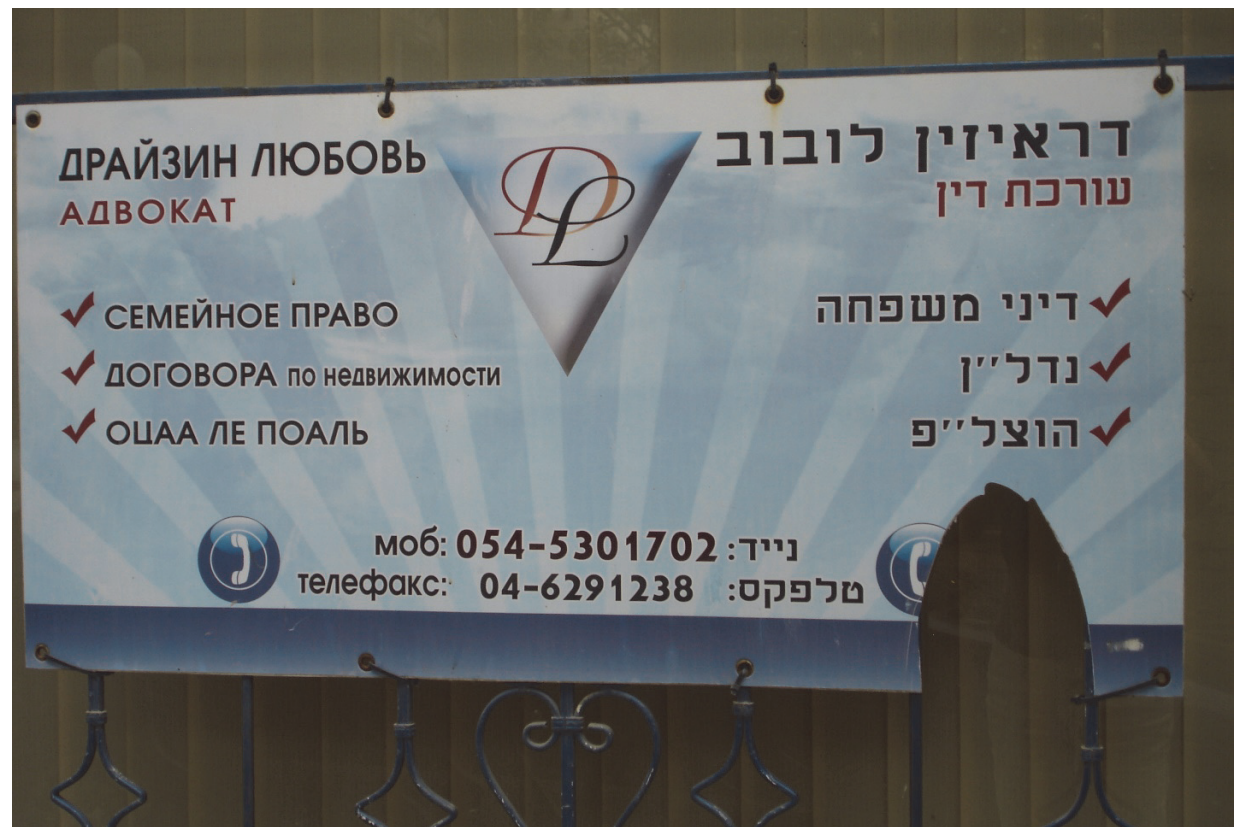

Figure 13. Listing areas of her specialization, the lawyer who placed this ad failed to find an appropriate translation for the term "carrying out court orders" and only managed to bring it closer to her Russian clients by transliterating it in Cyrillic

Common language as part of the common mentality helping to succeed in legal issues is a key theme on these webpages. Although many of the Russian-speaking lawyers today are members of the one-and-a-half, or second-generation immigrants and studied law in Israel, they have inherited the attitude of their Soviet-bred parents who viewed the individual's relations with the state as confrontational. No wonder then that a successful lawyer, Igor Glider, known for his public activities and defense of issues important for the Russian-speaking community, puts as a motto on his webpage an antithetical paraphrase of a speech cliché, alluding to the Soviet movie "Officers":

Есть такая профессия - людей от Родины защищать [There is a profession to defend citizens from their Fatherland] (18).

\section{SYMBOLIC ASPECTS OF LINGUISTIC LANDSCAPE}

Urban space is not only physically but also socially organized, and besides the instrumental function, signs often carry symbolic meaning. Following Jaworski and Thurlow, we believe that in the studies of LL the focus should be not so much on space per se as on spatialization, the different processes by which space comes to be represented, organized and experienced (2010: 6). Imagery of space becomes an important resource for immigrant communities to domesticate the city by filling it with familiar symbols, be they names, pictures and emblems, or allusions to precedent texts of the home culture. Onomastics of a contemporary city is a source of mass linguistic creativity (see Remchukova 2015), and in a multilingual city it gives us a glimpse of creative techniques used by bi- and multilinguals.

Like immigrants in other countries, Russian-speaking Israelis often give their businesses proper names. Immigrant-owned boutiques, beauty parlors and cosmetic shops 
have introduced Israelis to a wide repertoire of Russian and Ukrainian female names placed on the signs: e.g., Tatiana, Svetlana, Liudmila, Helenka, while magnet stickers attached to mailboxes and advertising handymen taught them Russian male names. Two business names in our sample are of particular interest. One is a grocery store which used to be called Putin - 24 hours. After expanding and remodeling the shop, the owners changed the name to Путин ликёр, with "Putin" written in Latin letters and "liqueur" in Hebrew [fig. 14]. Despite the provocative nature of the name - or thanks to it - the shop thrives although its repertoire of goods and prices does not differ much from other Russian grocery stores open at weekends. Notably, the name of this store sometimes appears on the list of sponsors of the Russian community's cultural events, e.g., $K V N$ contests. The second example comes from a gentrifying port area of Haifa where one can find a restaurant called Venya Bistro. It was launched by the Israeli artist Shahar Sivan who has no Russian roots but was inspired by Venedikt Erofeev's novel Москва - Петушки translated into Hebrew (19). The novel has become popular among Hebrew-speaking intelligentsia, but it is not clear whether the name of the restaurant is transparent to all its guests. Unfortunately, the website of the restaurant doesn't mention the antecedents of its name (20).

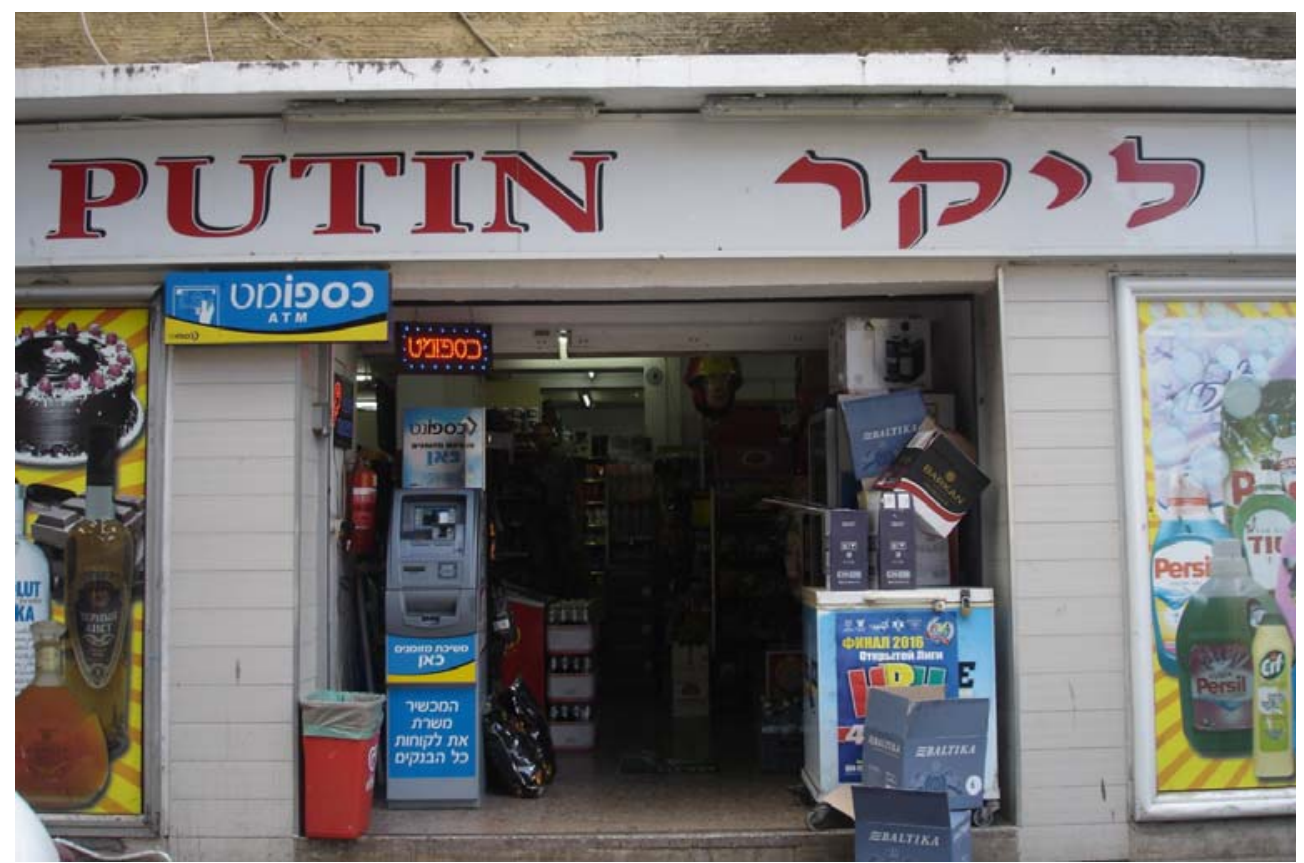

Figure 14. The "Russian" grocery Putin liqueur has a bilingual English-Hebrew sign. It is open seven days a week, working on Sabbath and holidays, when most of the shops in the Jewish sector are closed. The name is well known in town and serves as a marketing gimmick

Many businesses of different profiles are names of FSU cities or countries: bookstores Москва and Петербург, restaurants Ташкент and Georgia, a deli Odessa, etc. [fig. 15]. Like other signs in town, these are either Russian-Hebrew bilingual or Latin transliterations, although according to the city regulations, every sign should include Hebrew. Movies are also a source of inspiration for owners of businesses: A restaurant in Hadar is called 
Скрипач на крыше [Fiddler on the roof] and the sign is only in Russian. Several blocks away from it there is a small take-away Mimino. The sign is in Hebrew and English, but once inside, customers can find a Russian menu and speak Russian to the waitresses. The Soviet cult movie Mimino is not familiar to members of the Israeli public and the name rich in associations for FSU immigrants is unmotivated for Hebrew-speaking Israelis [fig. 16].

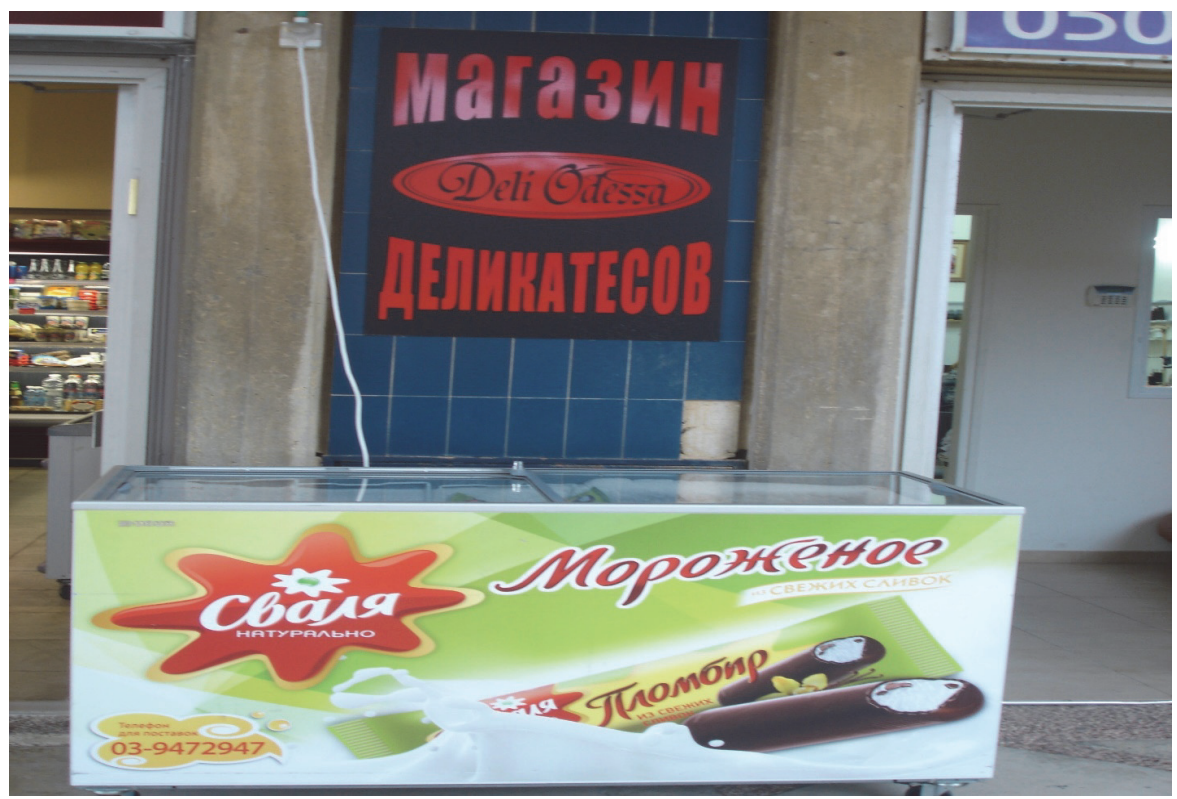

Figure 15. Deli Odessa is located in a prosperous neighborhood where the concentration of Russian-speaking residents is not high, but all the price tags appear both in Hebrew and in Russian, including Lithuanian ice cream Сваля [Svalia]

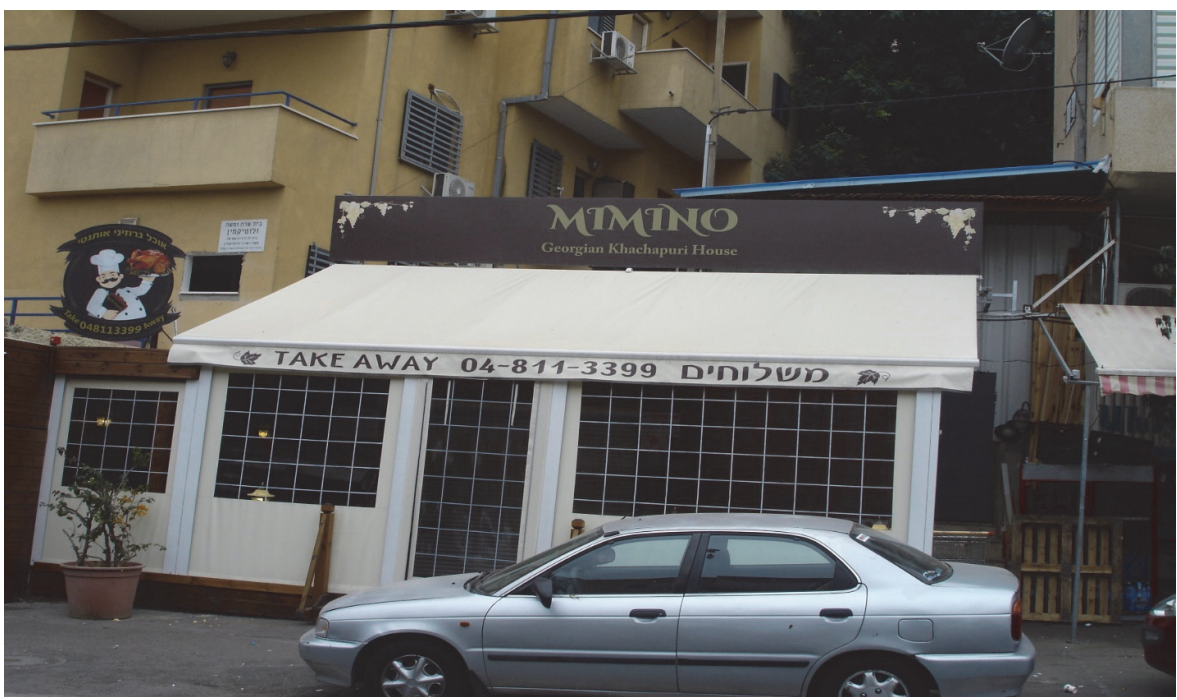

Figure 16. The takeaway Mimino advertises itself in English as a "Georgian Khachapuri House", however, a chef smiling from a Hebrew sign has a menu promising "Delivery" and carries a dish with a fried chicken. The advantage is that unlike khachapuri, a chicken looks familiar to any Hebrew or Arabic speaker irrespective of their prior acquaintance with the Georgian cuisine 
Among the Russian grocery stores of Haifa one can find Елисеевский [Eliseevs' grocery store] and Гастроном № 1 [Supermarket \# 1]. The two stores of Moscow and St. Petersburg, owned in pre-revolutionary times by brothers Eliseev, preserved the luxury of decoration in the Soviet time. In informal discourse in both cities these stores were and are still called "Eliseevskii". Even in the periods of food shortages, these two were a little better supplied than their less fortunate neighbors, and both were the source of urban legends about treasures allegedly hidden in their interior decoration by the exowners. The post-Soviet TV series, «Дело Гастронома № 1» [The case of Supermarket \# 1] about a corruption scandal associated with the store made it familiar to Russian TV viewers in the metropolis and in the diaspora, increasing the persuasive power of the sign for Russian-speaking customers.

One of the Russian-owned souvenir shops catering to tourists and residents alike, and offering Russian Orthodox icons as well as ritual objects related to Judaism, Russian children books and porcelain made in China is called RublËvka [fig. 17]. In small letters in Hebrew the sign indicates that it is a gift shop. But the name itself and the play with the Latin and Cyrillic alphabets speak volumes to Russian-speaking clients and do not require any clarifications. The name carries a constellation of connotations: it is a slightly pejorative name of a one-ruble bill (which no longer exists though, as it was replaced in the post-Soviet period by a coin); it is the informal name of a highway in the Western part of Moscow suburbs and it is also the informal name of an area near Moscow abounding in luxurious villas. As Rublevka is often mentioned in the media and was popularized by a TV series under the same name, its connotations are well familiar to Russian-speaking Israelis. The name has the aura of elite lifestyle but also of corruption and criminality. When we asked the salesperson in the shop about its name she laughed and said:

Не знаю, хозяин так решил. Ведь это прикольно: съездил в Израиль, побывал на Рублевке. [I don't know, this was the owner's idea. Look, it's cool: You've come to Israel for a trip and you've visited Rublevka.]

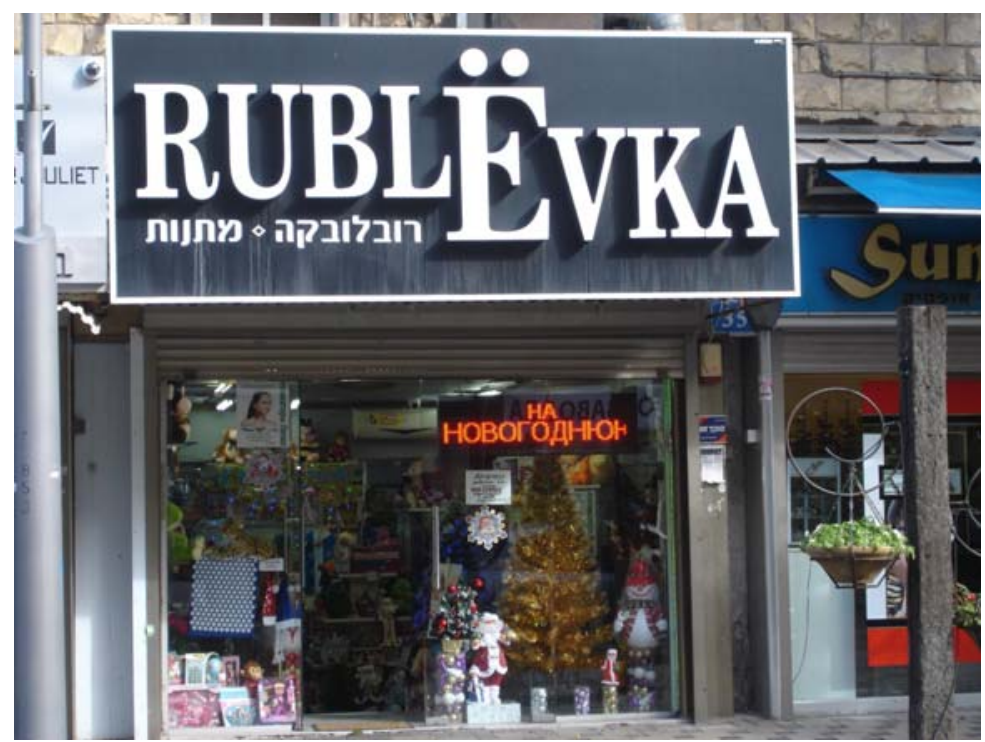

Figure 17. The running line wishing customers of the Rublevka store a Happy New Year is in Russian 
Not all the signs alluding to immigrants' background knowledge are rooted in mass culture. A Russian booking office selling tickets for Russian-Israeli theater performances, as well as for shows of touring artists from the FSU is called "Haifa Seasons", alluding to "Russian seasons" organized by the art connoisseur and entrepreneur Sergey Diagilev in Paris in 1908 and later in other European cities. Theater festivals conducted in postSoviet times, and called Moscow, Petersburg, and Paris Seasons have turned these names into a cliché implying elitist art and attracting audiences [fig. 18]. Sometimes Israeli businesses whose names allude to Russian culture look rather shabby, and may be perceived as a parody of what they allude to, yet the appeal of famous names is symbolically so strong that the owners count on the image of the source to outweigh the reality.

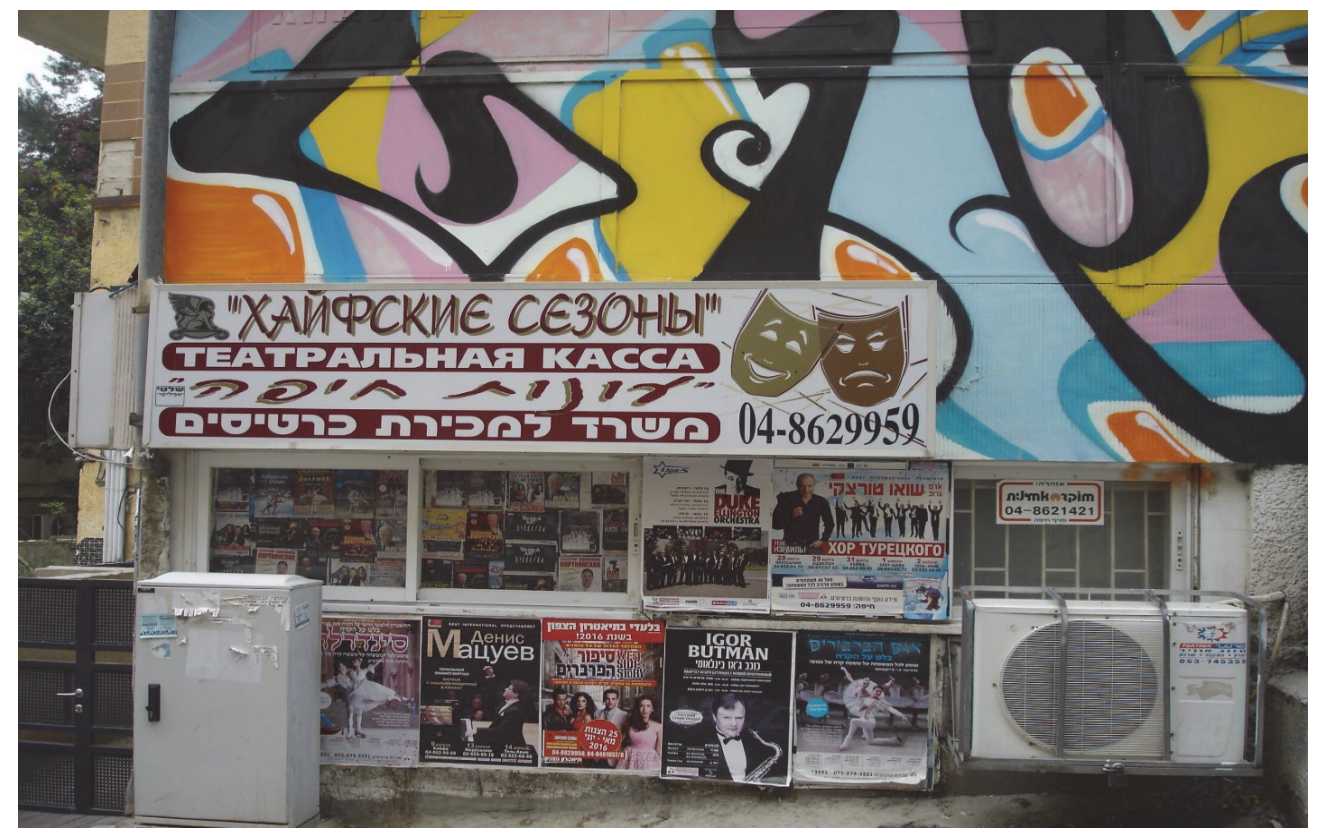

Figure 18. The booking office Haifa Seasons is tiny but the walls around it are always covered with theater posters. Although the agency specializes in selling tickets for performances by touring artists from the FSU, some of the posters are bilingual targeting the mainstream Israeli audience

Cultural allusions in the names of businesses build bridges between countries and also between generations. An ultraorthodox religious family opened a small MiddleEastern eatery in an affluent area of Haifa and called it Berdichev humus. Bringing together a Jewish-Ukrainian town (21) and a favorite Middle-Eastern appetizer, the name sounds like an oxymoron. This doesn't bother the owner who told us he was in love with Middle-Eastern dishes but also wanted to commemorate his great grandparents who decided to leave their native Berdichev when it was still part of the Russian Empire.

\section{CONCLUSIONS}

The project reported in this essay shows that almost 30 years after the beginning of the big wave of immigration from the FSU the vitality of the Russian language in Israel remains strong and it continues to be in demand in public life and in commercial 
activities. While it is unevenly represented in the signage of different urban areas, it has become an integral part of the overall LL of Israel. Although hesitantly and unsystematically, state-run institutions have integrated Russian into written language addressed to the residents. Virtual LL complements its physical counterpart and is often better developed than the latter. This, however, leaves the most vulnerable sections of the population, the elderly and socio-economically weak, dependent on Russian-speaking office staff. These categories of residents often lack Hebrew proficiency and are not technologically savvy. Multilingualism, especially proficiency in English and Russian, has become a valuable resource for those seeking office jobs, but is not reflected in the wages.

Israeli physical and virtual LL reveals that texts written in Russian target both domestic and international users. The latter are represented by potential immigrants from the CIS countries exploring their prospects in Israel, as well as tourists and business partners in these countries and other countries with sizeable groups of Russian speakers, e.g., Germany, the U.S.A. and Canada. In all these contacts Russian has evolved into a lingua franca. Our photo-archive confirms it is the only language spoken by FSU immigrants that is visible in the LL on top-down but also on bottom-up signs. Russian has also become a component of the multilingual Israeli translanguaging used both in informal and in formal discourse.

The names of many Russian-owned businesses show mobility of the symbols: pictures of the Red Square in the windows of travel agencies, restaurants named after characters of Russian folklore and Soviet cult movies, shops alluding to elite life styles in Russia - all of them serve to appeal to Russian-speaking Israelis and FSU tourists but are most often semiotically blank for veteran Israelis and thus incomprehensible, which sometimes triggers abusive overwriting on posters or walls, confirming that language contact is not immune to language conflict (Nelde 1987.)

(C) Maria Yelenevskaya, \& Larisa Fialkova, 2017

\section{NOTES}

(1) We would like to thank anonymous reviewers for helpful suggestions they made after reading the draft version of this essay.

(2) Counting languages in a multilingual country is a risky enterprise. Although Éthnologue is often cited, it has omissions. For example, the quoted edition does not include French, which is increasingly present in the public space of Israel due to a recent surge in immigration from France. Neither does it mention languages of the FSU, such as Georgian, Tat, Kazakh, Lithuanian, and some others spoken in Israel.

(3) http://9tv.co.il/news/2014/02/09/168734.html, last accessed 25 August 2014.

(4) http://www.kontinent.org/article.php?aid=510b98e55de9a, last accessed 12 November 2016.

(5) http://www.israelpost.co.il/HPcontent.nsf/EntryHomePage?ReadForm\&L=RU, last accessed 15 November 2016.

(6) Some of the Israeli banks had been founded before the state of Israel came into existence. In 1983 most of them were nationalized after a crash of bank stocks. Although later the state sold a large part of its holdings, it still remains a large share-holder (http://www.boi.org.il/en/DataAndStatistics/ Pages/Default.aspx, last accessed 20 May, 2017.) When new immigrants arrive in Israel they open an account in the bank of their choice. The benefits paid by the state to support them throughout the first period of life in Israel are transferred to their bank accounts. For Russian 
speakers who arrive in Israel without knowing Hebrew or English the choice of a bank may depend on whether they find employees that are able to communicate with them in their mother tongue.

(7) Amharic is the language of approximately 135,000 Jews of Ethiopian descent. They arrived in Israel in two major waves in 1984 and 1992.

(8) http://www.leumi-ru.co.il/home03/leumi_internet/9345/, last accessed on 12 January 2017.

(9) https://www.fibi.co.il/fibi/site/RU/Exclusive.htm, last accessed 22 November 2016.

(10) http://www.bankhapoalim.com/, last accessed 14 November 2016.

(11) http://www.nazareth-illit.muni.il/Russ/Pages/Moadoniim.aspx, last accessed 27 May 2017.

(12) http://www.haifa.muni.il/Pages/default.aspx, 16 November 2016. City life in Haifa is well represented in Russian on Facebook. There are several active public groups, numbering thousands of members, the most popular being Haifa.Ru.co.il with 13, 475 registered members, https://www.facebook.com/groups/228377432160/, last accessed 26 May 2017.

Besides exchanging city news, participants advertise their businesses, offer objects for sale, look for jobs and advertise jobs, etc. Virtual discussions in these groups are often bilingual, with some participants writing in Hebrew and others answering in Russian and vise-versa.

(13) http://www.isracity.com/haifa/state/bituachleumy.html, 20 October 2016.

(14) http://www.israelsale.ru/haifa.htm, 20 October 2016.

(15) KVN - the Club of the Witty and Resourceful is a student cabaret and a popular Soviet/Russian TV show that enjoys popularity both in Russia and in the diaspora.

(16) http://www.jewishpress.com/news/breaking-news/more-than-three-million-tourists-visitedisrael-in-2015/2016/01/11/, 30 November 2016.

(17) http://www.advokat-v-haife.co.il, 1 December 2016.

(18) http://infolaw.co.il/, last accessed on 12 December 2016. The original sentence from the movie is "There is a profession to defend one's Fatherland".

(19) V. Erofeev's novel Москва-Петуики [Moscow-Petushki, also known as "Moscow circles" and "Moscow End of the line station] was translated into Hebrew with commentaries by Nili Mirsky. Unfortunately, some of the deviations from the original remained unexplained. For example, the names of the cocktails and some of their ingredients were changed: Поцелуй тети Клавы [Aunt Klava's kiss] was transformed into neshikat ha-doda Klara [Aunt Clara's kiss]. Although the implications of the unpleasantness of a kiss with an elderly woman was preserved, a Russian Клава turned into a Jewish Clara. In the cocktail Сучий Потрох [literally "bitch's giblets", a curse connoting that someone is a scoundrel], one of the ingredients is shampoo Садко-богатый госmb [Sadko: a rich merchant] was replaced by shampoo Boris Godunov. Apparently, the translator chose the title of the opera that is better known to the Israeli audience.

(20) http://www.venya.co.il/about/, 10 December 2016.

(21) Before World War I, Berdichev was the biggest Jewish center in Ukraine and for its flourishing Yiddish culture was also known as Волынский Иерусалим [Volyn Jerusalem)

\section{REFERENCES}

Abousnnouga, G., \& Machin, D. (2010) War monuments and the changing discourses of war and soldiery. In Jaworski, A., \& Thurlow, C. (eds.), Semiotic Landscapes: Language, Image, Space. London, New York: Continuum, 219-240.

Aronin, L., \& O. Laoire, M. (2013) The material culture of multilingualism: Moving beyond the linguistic landscape. International Journal of Multilingualism, 10(3): 225-235.

Backhaus, P. (2007) Linguistic Landscape: A Comparative Study of Multilingualism in Tokyo. Clevedon: Multilingual Matters.

Barni, M., \& Bagna, C. (2010) Linguistic Landscape and Language Vitality. In Ben-Rafael, E., Shohamy, E., \& Barni, M. (eds.) Linguistic Landscape in the City. Clevedon, Buffalo, Toronto: Multilingual Matters, $3-18$. 
Ben Rafael, E., Shohamy, E., Amara M., \& Trumper-Hecht, N. (2006) Linguistic Landscape as Symbolic Construction of the Public Space: The Case of Israel. In Gorter, D. (ed.), Linguistic Landscape: A New Approach in Multilingualism. Clevedon, Buffalo, Toronto: Multilingual Matters, $7-30$.

Ben Rafael, E., \& Ben Rafael, M. (2010) Diaspora and returning diaspora: French-Hebrew and vice versa. In Shohamy, E., Ben Rafael, E., \& Barni, M. (2010) Linguistic Landscape in the City. Bristol, Buffalo, Toronto: Multilingual Matters, 326-343.

Coupland, N. (2010) Welsh linguistic landscapes "from above" and "from below". In Jaworski, A., \& Thurlow, C. (eds.). Semiotic Landscapes: Language, Image, Space. London, New York: Continuum, 77-101.

Deutch, Y. (2005). Language law in Israel. Language Policy, 4: 261-285.

Elias, N., \& Greenspan, L. (2007). The honey, the bear and the violin: Russian voices in Israeli advertising. Journal of Advertising Research, 47(1): 113-122.

Fialkova, L. (1999) Russkii yazyk v Izrail'skoi torgovle. Yazyk emigrantov v svete sotsiolingvistiki (The Russian Language in Israel's retailing, in Russian), Russistika segodnya, 1-2: 80-89.

Fialkova, L. (2007) Koly Hory Shkodiat'sia: Narysy z Ukrain'sko-izrail'skykh Fol'klornykh Vzemyn (When Mountains Meet: Essays in Ukrainian-Israeli Folklore, in Ukrainian.) Kyiv: Institute of Art Studies, Folklore and Ethnology, Ukrainian Academy of Sciences.

Fialkova, L., \& Yelenevskaya, M. (2011) Immigrants in the City: From Exploration to Domestication, Israel Affairs, 17 (1): 143-164.

Fialkova, L., \& Yelenevskaya, M. (2013) In Search of the Self: Immigrants': Reconciling the Past and the Present in Immigrants' Experience. Tartu: ELM Scholarly Press.

Fialkova, L., \& Yelenevskaya, M. (2013a) Liubimyi prazdnik: Novyi god v emigrantskoi srede v Izraile (Our Favorite Holiday: New Year Celebrations among Immigrants to Israel, in Russian). In L. Fedorova (ed.), Ritual v yazyke i kommunikatsii, Moscow: JSK-RGGU, 255-265.

Fialkova, L., \& Yelenevskaya, M. (2015) The Crisis in Ukraine and the Split of Identity in the Russianspeaking World. Folklorica, XIX: 101-132.

Glinert, L.H. (1995) Inside the language planner's head: Tactical responses to a mass immigration. Journal of Multilingual and Multicultural Development, 16(5): 351-371.

Golan-Cook, P., \& Olshtain, E. (2011) A model of identity and language orientation: The case of immigrant students from the former Soviet Union in Israel. Journal of Multilingual and Multicultural Development, 32(4): 361-376.

Gorter, D. (2006) Introduction: The Study of linguistic landscape as a new approach to multilingualism. In Gorter, D. (ed.), Linguistic Landscape: A New Approach in Multilingualism. Clevedon, Buffalo, Toronto: Multilingual Matters, $1-6$.

Jaworski, A., \& Thurlow, C. (2010) Introducing Semiotic Landscapes. In Jaworski, A., \& Thurlow, C. (eds.), Semiotic Landscapes: Language, Image, Space. London, New York: Continuum, $1-40$.

Kelly-Holmes, H. (2005) Advertising as Multilingual Communication. New York: Palgrave Macmillan.

Kheimets, N., \& Epstein, A. (2001) English as a central component of success in the professional and social integration of scientists from the former Soviet Union in Israel. Language and Society, 30(2): $121-143$.

Khvorostianova, N., \& Elias, N. (2008) Staryi dom na novoi ulitse? Kul'turnye instituty "russkoi obschiny Ber-Shevy (An old home in a new street? Cultural institutions of the "Russian" Community in Beer-Sheva, in Russian.) In Nosenko, E. (ed.) Israil' glazami "russkikh": Kul'tura i identichnost'. Moscow: Natalis, 304-328. 
Kliuchnikova, P. (2015) Language attitudes and "folk linguistics" of Russian-speaking migrants in the UK. Russian Journal of Communication, 7(2): 179-192.

Kopeliovich, Sh. (2013) "Happylingual": A family project for enhancing and balancing multilingual development. In Schwartz, M., \& Verschik, A. (eds.), Successful Family Language Policy: Parents, Children and Educators in Interaction. Dordrecht, Heidelberg, New York, London: Springer, 249-276.

Landry, R., \& Bourhis, R.Y. (1997) Linguistic landscape and ethnolinguistic vitality: An empirical study. Journal of Language and Social Psychology 16, 23- 49.

Lewis, M. P., Simons, G. F., Fenning, C. D. (eds.) (2016) Ethnologue: Languages of the World, $19^{\text {th }}$ edition. Dallas, Texas: SIL International. Online version: http://www.ethnologue.com, last accessed 15 Sept. 2016.

Marten, H. F., Mensel, L.Van, \& Gorterm D. (2012) Studying minority languages in the linguistic landscape. In Gorter, D., Marten, H. F., \& Mensel, L. van (eds.), Minority Languages in the Linguistic Landscape. New York: Palgrave Macmillan, 1-18. Buffalo, Toronto: Multilingual Matters, 182-198.

Mustajoki, A., \& Protassova, E. (2014) Russkii sredi drugikh yazykov Finliandii: Aktual'nye problemi (Russian among other languages of Finland: Current Problems, in Russian) In Gasparov, B.M., \& Kupina, N.A. (eds.), Russkii yazyk mnogorechnom sotsiokul'turnom prostranstve. Ekaterinburg: Ural University Press, 220-239.

Nelde, P. (1987) Language contact means language conflict. Journal of Multilingual and Multicultural Development, $8(1-2)$ : $33-42$.

Pavlenko, A. (2010) Linguistic landscape of Kyiv, Ukraine: A diachronic study. In Ben-Rafael, E., Shohamy, E., \& Barni, M. (eds.) Linguistic Landscape in the City. Clevedon, Buffalo, Toronto: Multilingual Matters, 133-152.

Pennycook, A. (2010) Graffscapes and city souls. In Jaworski, A., \& Thurlow, C. (eds.), Semiotic Landscapes: Language, Image, Space. London, New York: Continuum, pp. 137-150.

Perotto, M., \& Niznik, M. - Перотто, М. и Низник, М. (2014) Po-russki govorim my s detstva. Iz opyta neformal'nogo obuchenia russkomu yazyku v Izraile i Italii. (We have been speaking Russian since childhood: On the experience of informal teaching of the Russian language in Israel and Italy, in Russian.) In Nikunlassi, A., \& Protassova, E. (eds.) Slavica Helsingiensia, 5. Instrumentarium of Linguistics. Helsinki, 75-95.

Remchukova, E. (2015) Aktual'nye napravlenia sovremennoi rusistiki: sfera gorodskoi nominatsii kak ob'ekta lingvisticheskogo kreativa (Current trends in Russian studies: Name giving in in the city as an area of linguistic creativity, in Russian.) Russkii yazyk i literatura v prostranstve mirovoi kul'tury. Proceedings of the $13^{\text {th }}$ Congress of the International association of the teachers of Russian Language and literature, 8: 253-258.

Remennick, L. (2008) «Russkie» izrail'tiane glazami sotsiologa: kul'tura i obraz zhizni (Cultural affiliation and lifestyles of Russian-speaking Israelis: A sociological view, in Russian.) In Nosenko, E. (ed.), Israel through "Russian Eyes": Identities and Cultures. Moscow: Natalis, 167-185.

Schwartz, M., \& Verschik, A. (2013) Achieving success in family language policy: Parents, children and educators in interaction. In Schwartz, M., \& Verschik, A. (eds.), Successful Family Language Policy: Parents, Children and Educators in Interaction. Dordrecht, Heidelberg, New York, London: Springer, $1-22$.

Shifman, L., Katz, E. (2005) "Just call me Adonai": A case study of ethnic humor and immigrant assimilation. American Sociological Review, 70 (5), 843-859.

Spolsky, Bernard (2001) Language in Israel: Policy, practice and ideology. In Alatis, J. E., \& Tan, A.H. (eds.), Language in Our Time: Bilingual Education and Official English, Ebonics and Standard English, Immigration and the Unz Initiative. Washington D.C. George Town University Press, $164-174$. 
Spolsky, B. (2009) Prolegomena to a sociolinguistic theory of public signage. In Shohamy, E., \& Gorter, D. (eds.), Linguistic Landscape: Expanding the Scenery. London: Routledge, pp. 25-38.

Spolsky, B., \& Cooper, R. (1991) Languages of Jerusalem. Oxford: Clarendon Press.

Tolts, M. (2011) Demography of the contemporary Russian-speaking Jewish diaspora. Paper presented at the conference Contemporary Russian-speaking Jewish Diaspora, Harvard University, https://www.researchgate.net/publication/233985633_Demography_of_the_Contemporary_ Russian-Speaking_Jewish_Diaspora, last accessed 27 May, 2017.

Woldemariam, H., \& Lanza, E. (2015) Imagined community: The linguistic landscape in a diaspora. Linguistic Landscape, 1 (1-2): 172-190.

Yelenevskaya, M. (2015) An immigrant language in a multilingual state: Status and competition. Russian Journal of Communication, 7(2), pp. 193-207.

Yelenevskaya, M., \& Fialkova, L. (2005) Russkaia ulitsa v evreiskoi strane. Issledovanie fol'klora emigrantov 1990-kh v Izraile, v 2-kh tomakh (Russian street in the Jewish state. Research into the folklore of the emigrants of the 1990s in Israel, in Russian), 2 volumes. Moscow: Russian Academy of Sciences.

Yelenevskaya, M. and Fialkova, L. (2006) Between dream cities and reality: Personal narratives of Ex-Soviets in Israel. Applied Research for the Quality of Life, No. 1, 189-209.

Yelenevskaya, M., \& Fialkova, L. (2012) "Holiday of Holidays" Festival in Haifa: Between Hope and Reality. Cultural Analysis, 10: 141-156, http://socrates.berkeley.edu/ caforum/volume10/ vol10_events2.html.

Yuniverg, L. (2015) Russkoe knizhnoe delo v Izraile (Russian book industry in Israel, in Russian). Russkoe literaturnoe echo, http://www.eholit.ru/news/786/, last accessed 10 November 2016.

Zbenovich, C., \& Lerner, J. (2013) Vospitanie - eto rabota: Intercultural Encounters in educational communication within Russian-speaking families on Israel. Russian Journal of Communication, 5(2): $119-140$.

Zukin, S. (1998) Urban lifestyles: Diversity and standardization in spaces of consumption. Urban Studies, 35 (5/6): 825-839.

\section{Article history:}

Received: 20 March 2017

Revised: 10 May 2017

Accepted: 16 June 2017

\section{For citation:}

Yelenevskaya, M., Fialkova, L. (2017). Linguistic Landscape and What It Tells Us about the Integration of the Russian Language into Israeli Economy. Russian Journal of Linguistics, 21 (3), 557-586. doi 10.22363/2312-9182-2017-21-3-557-586

\section{Bio Notes:}

Maria Yelenevskaya, Ph.D., head of Computer-Assisted Language Learning Laboratory in the Department of Humanities and Arts at the Technion-Israel Institute of Technology. Research interests: the use of language in multilingual and multicultural settings, lingua-cultural aspects of computer-mediated communication and investigation of humor. In collaboration with Larisa Fialkova she has written 28 articles and three monographs. Her professional activities include organization of conference panels, editorial work and reviewing for various journals. She is on the editorial board of two linguistic journals and Israel Association for the Study of Language and Society. Contact information: e-mail: ymaria52@technion.ac.ie. 
Larisa Fialkova, Ph.D., Lecturer in the Department of Hebrew and Comparative Literature at the University of Haifa. Research interests: Russian literature, Slavic and contemporary folklore. She teaches various courses, among them: Folklore and Immigration, Folklore in the Era of High-tech, The Image of the Other in Folklore, Russian and Ukrainian folklore in English, Hebrew, Russian and Ukrainian and so on. In collaboration with M. Yelenevskaya she has written 28 essays and 3 joint monographs. Contact information: e-mail: lara@research.haifa.ac.il.

\title{
ЯЗЫКОВОЙ ЛАНДШАФТ: ЧТО ОН НАМ ГОВОРИТ ОБ ИНТЕГРАЦИИ РУССКОГО ЯЗЫКА В ЭКОНОМИКУ ИЗРАИЛЯ
}

\author{
Мария Еленевская ${ }^{1}$, Лариса Фиалкова ${ }^{2}$ \\ ${ }^{1}$ Политехнический институт Израиля \\ Technion City, 3200003 Haifa, Israel \\ ${ }^{2}$ Университет Хайфы \\ Ave. Abakhoushy Mount Carmel, 3498838 Haifa, Israel
}

\begin{abstract}
Статья посвящена использованию русского языка в лингвистическом ландшафте Израиля. Несмотря на государственную поддержку гегемонии иврита и лишь неохотные и бессистемные уступки многоязычию, русский язык распространен во всех сферах общественной жизни. Письменные тексты на русском языке, маркирующие городское пространство Израиля, неравномерно представлены в разных районах и свидетельствуют об этнической и социальной стратификации израильских городов. Наибольшая концентрация русских надписей наблюдается в коммерческих и туристических районах: они адресованы и русскоязычным израильтянам, и зарубежным туристам. В статье анализируется использование русского в тех сферах государственного и коммерческого секторов, которые требуют интенсивного использования языка. Особое внимание уделено использованию культурных символов в качестве маркетинговой стратегии.
\end{abstract}

Ключевые слова: лингвистический ландшафт, многоязычие, иммигранты, лингвистические ресурсы, экономика символов

\section{История статьи:}

Дата поступления в редакцию: 20 марта 2017

Дата принятия печати: 16 июня 2017

Для цитирования:

Yelenevskaya, M., Fialkova, L. Linguistic Landscape and What It Tells us about the Integration of the Russian Language into Israeli Economy // Вестник Российского университета дружбы народов. Серия: Лингвистика. 2017. Т. 21. № 3. С. 557-586. doi 10.22363/2312-9182-201721-3-557-586

\section{Сведения об авторах:}

Мария Еленевская, доктор филологических наук, заведующая лабораторией по использованию компьютерных технологий в обучении иностранным языкам на кафедре гуманитарных наук в Политехническом институте Израиля. Сфера научных интересов: функционирование языка в многоязычном и многокультурном обществе, лингвокультурные особенности интернет-коммуникации, а также исследования юмора. Среди ее многочисленных публикаций -28 статей 
и три монографии, написанные в соавторстве с Ларисой Фиалковой. Ее профессиональная деятельность включает подготовку спецвыпусков журналов, организацию секций на научных конференциях и работу в редколлегии двух лингвистических журналов и Израильской ассоциации исследования языка и общества. Контактная информаџия: e-mail: ymaria52@ technion.ac.ie.

Лариса Фиалкова, кандидат филологических наук, преподаватель кафедры ивритской и сравнительной литературы в Университете Хайфы. Сфера научных интересов: русская литература, славянский и современный фольклор. Она подготовила и читает различные курсы, среди которых: «Фольклор и иммиграция», «Фольклор в эпоху высоких технологий», «Образ чужака в фольклоре» и т.д. Ее профессиональная деятельность включает работу в редколлегии научных журналов, организацию конференций и подготовку спецвыпусков. Ее многочисленные публикации, написанные на русском, английском, украинском языках и на иврите, посвящены русской литературе, а также русскому и украинскому фольклору. Три монографии и 28 статей, посвященных языку и культуре выходцев из бывшего СССР в Израиле, написаны в соавторстве с Марией Еленевской. Контактная информачия: e-mail: lara@research.haifa.ac.il. 